\title{
Adhesion Class GPCRs (version 2019.4) in the IUPHAR/BPS Guide to Pharmacology Database
} \author{
Wolfrum ${ }^{8}$ and Lei $\mathrm{Xu}{ }^{16}$ \\ 1. University of Chicago, USA \\ 2. University of Leipzig, Germany \\ 3. National Institute of Mental Health, USA \\ 4. University of Hamburg, Germany \\ 5. King's College London, UK \\ 6. University of Amsterdam, The Netherlands \\ 7. Washington University, USA \\ 8. Johannes-Gutenberg Universitaet Mainz, Germany \\ 9. Uppsala Universitet, Sweden \\ 10. Chang Gung University, Taiwan \\ 11. Stanford University, USA \\ 12. Boston Children's Hospital, USA \\ 13. Uppsala University, Sweden \\ 14. University of Leeds, UK \\ 15. University of Kent, UK \\ 16. University of Rochester, USA
}

Demet Arac-Ozkan ${ }^{1}$, Gabriela Aust ${ }^{2}$, Tom I. Bonner ${ }^{3}$, Heike Cappallo-Obermann ${ }^{4}$, Caroline Formstone ${ }^{5}$, Jörg Hamann $^{6}$, Breanne Harty ${ }^{7}$, Henrike Heyne ${ }^{2}$, Christiane Kirchhoff ${ }^{4}$, Barbara Knapp ${ }^{8}$, Arunkumar Krishnan ${ }^{9}$, Tobias Langenhan ${ }^{2}$, Diana Le Duc ${ }^{2}$, Hsi-Hsien Lin ${ }^{10}$, David C. Martinelli ${ }^{11}$, Kelly Monk ${ }^{7}$, Xianhua Piao ${ }^{12}$, Simone Prömel $^{2}$, Torsten Schöneberg ${ }^{2}$, Helgi Schiöth ${ }^{13}$, Kathleen Singer ${ }^{12}$, Martin Stacey ${ }^{14}$, Yuri Ushkaryov ${ }^{15}$, Uwe

\begin{abstract}
Adhesion GPCRs are structurally identified on the basis of a large extracellular region, similar to the Class B GPCR, but which is linked to the 7TM region by a GPCR autoproteolysis-inducing (GAIN) domain [8] containing a GPCR proteolytic site. The N-terminus often shares structural homology with adhesive domains (e.g. cadherins, immunolobulin, lectins) facilitating inter- and matricellular interactions and leading to the term adhesion GPCR [82, 332]. Several receptors have been suggested to function as mechanosensors [254, 234, $315,32]$. The nomenclature of these receptors was revised in 2015 as recommended byNC-IUPHAR and the Adhesion GPCR Consortium [100].
\end{abstract}

\section{Contents}

This is a citation summary for Adhesion Class GPCRs in the Guide to Pharmacology database (GtoPdb). It exists purely as an adjunct to the database to facilitate the recognition of citations to and from the database by citation analyzers. Readers will almost certainly want to visit the relevant sections of the database which are given here under database links. 
GtoPdb is an expert-driven guide to pharmacological targets and the substances that act on them. GtoPdb is a reference work which is most usefully represented as an on-line database. As in any publication this work should be appropriately cited, and the papers it cites should also be recognized. This document provides a citation for the relevant parts of the database, and also provides a reference list for the research cited by those parts.

Please note that the database version for the citations given in GtoPdb are to the most recent preceding version in which the family or its subfamilies and targets were substantially changed. The links below are to the current version. If you need to consult the cited version, rather than the most recent version, please contact the GtoPdb curators.

\section{Database links}

\section{Adhesion Class GPCRs}

http://www.guidetopharmacology.org/GRAC/FamilyDisplayForward?familyld=17

Introduction to Adhesion Class GPCRs

http://www.guidetopharmacology.org/GRAC/FamilylntroductionForward?familyld=17

\section{Receptors}

\section{ADGRA1}

http://www.guidetopharmacology.org/GRAC/ObjectDisplayForward?objectld=197

ADGRA2

http://www.guidetopharmacology.org/GRAC/ObjectDisplayForward?objectld=198

ADGRA3

http://www.guidetopharmacology.org/GRAC/ObjectDisplayForward?objectld=199

ADGRB1

http://www.guidetopharmacology.org/GRAC/ObjectDisplayForward?objectld=174

ADGRB2

http://www.guidetopharmacology.org/GRAC/ObjectDisplayForward?objectld=175

ADGRB3

http://www.guidetopharmacology.org/GRAC/ObjectDisplayForward?objectld=176

CELSR1

http://www.guidetopharmacology.org/GRAC/ObjectDisplayForward?objectld=178

CELSR2

http://www.guidetopharmacology.org/GRAC/ObjectDisplayForward?objectld=179

CELSR3

http://www.guidetopharmacology.org/GRAC/ObjectDisplayForward?objectld=180 ADGRD1

http://www.guidetopharmacology.org/GRAC/ObjectDisplayForward?objectld=202 ADGRD2

http://www.guidetopharmacology.org/GRAC/ObjectDisplayForward?objectld=204

ADGRE1

http://www.guidetopharmacology.org/GRAC/ObjectDisplayForward?objectld=182 ADGRE2

http://www.guidetopharmacology.org/GRAC/ObjectDisplayForward?objectld=183 ADGRE3

http://www.guidetopharmacology.org/GRAC/ObjectDisplayForward?objectld=184 ADGRE4P

http://www.guidetopharmacology.org/GRAC/ObjectDisplayForward?objectld=185 ADGRE5

http://www.guidetopharmacology.org/GRAC/ObjectDisplayForward?objectld=177

ADGRF1 
http://www.guidetopharmacology.org/GRAC/ObjectDisplayForward?objectld=190

\section{ADGRF2}

http://www.guidetopharmacology.org/GRAC/ObjectDisplayForward?objectld=191 ADGRF3

http://www.guidetopharmacology.org/GRAC/ObjectDisplayForward?objectld=193 ADGRF4

http://www.guidetopharmacology.org/GRAC/ObjectDisplayForward?objectld=195 ADGRF5

http://www.guidetopharmacology.org/GRAC/ObjectDisplayForward?objectld=196 ADGRG1

http://www.guidetopharmacology.org/GRAC/ObjectDisplayForward?objectld=186

\section{ADGRG2}

http://www.guidetopharmacology.org/GRAC/ObjectDisplayForward?objectld=187 ADGRG3

http://www.guidetopharmacology.org/GRAC/ObjectDisplayForward?objectld=188 ADGRG4

http://www.guidetopharmacology.org/GRAC/ObjectDisplayForward?objectld=192 ADGRG5

http://www.guidetopharmacology.org/GRAC/ObjectDisplayForward?objectld=194 ADGRG6

http://www.guidetopharmacology.org/GRAC/ObjectDisplayForward?objectld=200 ADGRG7

http://www.guidetopharmacology.org/GRAC/ObjectDisplayForward?objectld=201 ADGRL1

http://www.guidetopharmacology.org/GRAC/ObjectDisplayForward?objectld=206 ADGRL2

http://www.guidetopharmacology.org/GRAC/ObjectDisplayForward?objectld=207

ADGRL3

http://www.guidetopharmacology.org/GRAC/ObjectDisplayForward?objectld=208

ADGRL4

http://www.guidetopharmacology.org/GRAC/ObjectDisplayForward?objectld=181

ADGRV1

http://www.guidetopharmacology.org/GRAC/ObjectDisplayForward?objectld=189

\section{References}

1. Aalto Y, El-Rifa W, Vilpo L, Ollila J, Nagy B, Vihinen M, Vilpo J and Knuutila S. (2001) Distinct gene expression profiling in chronic lymphocytic leukemia with 11q23 deletion. Leukemia 15: 1721-8 [PMID:11681413]

2. Abe J, Suzuki H, Notoya M, Yamamoto T and Hirose S. (1999) Ig-hepta, a novel member of the G proteincoupled hepta-helical receptor (GPCR) family that has immunoglobulin-like repeats in a long N-terminal extracellular domain and defines a new subfamily of GPCRs. J. Biol. Chem. 274: 19957-64 [PMID:10391944]

3. Akashi K, He X, Chen J, Iwasaki H, Niu C, Steenhard B, Zhang J, Haug J and Li L. (2003) Transcriptional accessibility for genes of multiple tissues and hematopoietic lineages is hierarchically controlled during early hematopoiesis. Blood 101: 383-9 [PMID:12393558]

4. Allache R, De Marco P, Merello E, Capra V and Kibar Z. (2012) Role of the planar cell polarity gene CELSR1 in neural tube defects and caudal agenesis. Birth Defects Res. Part A Clin. Mol. Teratol.94: 17681 [PMID:22371354]

5. Anderson KD, Pan L, Yang XM, Hughes VC, Walls JR, Dominguez MG, Simmons MV, Burfeind P, Xue Y and Wei $Y$ et al.. (2011) Angiogenic sprouting into neural tissue requires Gpr124, an orphan G protein- 
coupled receptor. Proc. Natl. Acad. Sci. U.S.A. 108: 2807-12 [PMID:21282641]

6. Antoni G, Morange PE, Luo Y, Saut N, Burgos G, Heath S, Germain M, Biron-Andreani C, Schved JF and Pernod $G$ et al.. (2010) A multi-stage multi-design strategy provides strong evidence that the BAl3 locus is associated with early-onset venous thromboembolism. J. Thromb. Haemost. 8: 2671-9 [PMID:20946148]

7. Araç D, Aust G, Calebiro D, Engel FB, Formstone C, Goffinet A, Hamann J, Kittel RJ, Liebscher I and Lin $\mathrm{HH}$ et al.. (2012) Dissecting signaling and functions of adhesion G protein-coupled receptors Ann. N. Y. Acad. Sci. 1276: 1-25 [PMID:23215895]

8. Araç D, Boucard AA, Bolliger MF, Nguyen J, Soltis SM, Südhof TC and Brunger AT. (2012) A novel evolutionarily conserved domain of cell-adhesion GPCRs mediates autoproteolysis. EMBO J. 31: 1364-78 [PMID:22333914]

9. Arcos-Burgos M, Jain M, Acosta MT, Shively S, Stanescu H, Wallis D, Domené S, Vélez JI, Karkera JD and Balog $\mathrm{J}$ et al.. (2010) A common variant of the latrophilin 3 gene, LPHN3, confers susceptibility to ADHD and predicts effectiveness of stimulant medication. Mol. Psychiatry 15: 1053-66 [PMID:20157310]

10. Ashton AC, Volynski KE, Lelianova VG, Orlova EV, Van Renterghem C, Canepari M, Seagar M and Ushkaryov YA. (2001) alpha-Latrotoxin, acting via two Ca2+-dependent pathways, triggers exocytosis of two pools of synaptic vesicles. J. Biol. Chem. 276: 44695-703 [PMID:11572875]

11. Aust G. (2010) Adhesion-GPCRS in tumorigenesis. Adv. Exp. Med. Biol. 706: 109-20 [PMID:21618830]

12. Aust G, Eichler W, Laue S, Lehmann I, Heldin NE, Lotz O, Scherbaum WA, Dralle H and Hoang-Vu C. (1997) CD97: a dedifferentiation marker in human thyroid carcinomas. Cancer Res. 57: 1798-806 [PMID:9135025]

13. Aust G, Hamann J, Schilling $N$ and Wobus M. (2003) Detection of alternatively spliced EMR2 mRNAs in colorectal tumor cell lines but rare expression of the molecule in colorectal adenocarcinomas. Virchows Arch. 443: 32-7 [PMID:12761622]

14. Aust G, Steinert M, Schütz A, Boltze C, Wahlbuhl M, Hamann J and Wobus M. (2002) CD97, but not its closely related EGF-TM7 family member EMR2, is expressed on gastric, pancreatic, and esophageal carcinomas. Am. J. Clin. Pathol. 118: 699-707 [PMID:12428789]

15. Aust G, Wandel E, Boltze C, Sittig D, Schütz A, Horn LC and Wobus M. (2006) Diversity of CD97 in smooth muscle cells. Cell Tissue Res. 324: 139-47 [PMID:16408199]

16. Austyn JM and Gordon S. (1981) F4/80, a monoclonal antibody directed specifically against the mouse macrophage. Eur. J. Immunol. 11: 805-15 [PMID:7308288]

17. Bahi-Buisson N, Poirier K, Boddaert N, Fallet-Bianco C, Specchio N, Bertini E, Caglayan O, Lascelles K, Elie $C$ and Rambaud J et al.. (2010) GPR56-related bilateral frontoparietal polymicrogyria: further evidence for an overlap with the cobblestone complex. Brain 133: 3194-209 [PMID:20929962]

18. Bai Y, Du L, Shen L, Zhang Y and Zhang L. (2009) GPR56 is highly expressed in neural stem cells but downregulated during differentiation. Neuroreport 20: 918-22 [PMID:19525879]

19. Baud V, Chissoe SL, Viegas-Péquignot E, Diriong S, N'Guyen VC, Roe BA and Lipinski M. (1995) EMR1, an unusual member in the family of hormone receptors with seven transmembrane segments. Genomics 26: 334-44 [PMID:7601460]

20. Beall SA, Boekelheide K and Johnson KJ. (2005) Hybrid GPCR/cadherin (Celsr) proteins in rat testis are expressed with cell type specificity and exhibit differential Sertoli cell-germ cell adhesion activity. J. Androl. 26: 529-38 [PMID:15955893]

21. Becker S, Wandel E, Wobus M, Schneider R, Amasheh S, Sittig D, Kerner C, Naumann R, Hamann J and Aust G. (2010) Overexpression of CD97 in intestinal epithelial cells of transgenic mice attenuates colitis by strengthening adherens junctions. PLoS ONE 5: e8507 [PMID:20084281]

22. Besnard T, Vaché $C$, Baux D, Larrieu L, Abadie C, Blanchet C, Odent S, Blanchet $P$, Calvas $P$ and Hamel C et al.. (2012) Non-USH2A mutations in USH2 patients. Hum. Mutat. 33: 504-10 [PMID:22147658]

23. Beyer RP, Fry RC, Lasarev MR, McConnachie LA, Meira LB, Palmer VS, Powell CL, Ross PK, Bammler TK and Bradford BU et al.. (2007) Multicenter study of acetaminophen hepatotoxicity reveals the importance of biological endpoints in genomic analyses. Toxicol. Sci. 99: 326-37 [PMID:17562736]

24. Bjarnadóttir TK, Fredriksson R, Höglund PJ, Gloriam DE, Lagerström MC and Schiöth HB. (2004) The 
human and mouse repertoire of the adhesion family of G-protein-coupled receptors. Genomics 84: 23-33 [PMID:15203201]

25. Bjarnadóttir TK, Geirardsdóttir K, Ingemansson M, Mirza MA, Fredriksson R and Schiöth HB. (2007) Identification of novel splice variants of Adhesion G protein-coupled receptors. Gene 387: 38-48 [PMID:17056209]

26. Bohnekamp J and Schöneberg T. (2011) Cell adhesion receptor GPR133 couples to Gs protein J. Biol. Chem. 286: 41912-6 [PMID:22025619]

27. Bolliger MF, Martinelli DC and Südhof TC. (2011) The cell-adhesion G protein-coupled receptor BAI3 is a high-affinity receptor for C1q-like proteins. Proc. Natl. Acad. Sci. U.S.A. 108: 2534-9 [PMID:21262840]

28. Boltze C, Schneider-Stock R, Aust G, Mawrin C, Dralle H, Roessner A and Hoang-Vu C. (2002) CD97, CD95 and Fas-L clearly discriminate between chronic pancreatitis and pancreatic ductal adenocarcinoma in perioperative evaluation of cryocut sections. Pathol. Int. 52: 83-8 [PMID:11940212]

29. Bonaglia MC, Marelli S, Novara F, Commodaro S, Borgatti R, Minardo G, Memo L, Mangold E, Beri S and Zucca $C$ et al.. (2010) Genotype-phenotype relationship in three cases with overlapping $19 p 13.12$ microdeletions. Eur. J. Hum. Genet. 18: 1302-9 [PMID:20648052]

30. Bonnet C, Grati M, Marlin S, Levilliers J, Hardelin JP, Parodi M, Niasme-Grare M, Zelenika D, Délépine M and Feldmann $D$ et al.. (2011) Complete exon sequencing of all known Usher syndrome genes greatly improves molecular diagnosis. Orphanet J Rare Dis 6: 21 [PMID:21569298]

31. Boucard AA, Ko J and Südhof TC. (2012) High affinity neurexin binding to cell adhesion G-protein-coupled receptor CIRL1/latrophilin-1 produces an intercellular adhesion complex. J. Biol. Chem. 287: 9399-413 [PMID:22262843]

32. Boyden SE, Desai A, Cruse G, Young ML, Bolan HC, Scott LM, Eisch AR, Long RD, Lee CC and Satorius CL et al.. (2016) Vibratory Urticaria Associated with a Missense Variant in ADGRE2.N. Engl. J. Med. 374: 656-63 [PMID:26841242]

33. Caddy J, Wilanowski T, Darido C, Dworkin S, Ting SB, Zhao Q, Rank G, Auden A, Srivastava S, Papenfuss TA, Murdoch JN, Humbert PO, Parekh V, Boulos N, Weber T, Zuo J, Cunningham JM and Jane SM. (2010) Epidermal wound repair is regulated by the planar cell polarity signaling pathway. Dev. Cell 19: 138-47 [PMID:20643356]

34. Caminschi I, Lucas KM, O'Keeffe MA, Hochrein H, Laâbi Y, Köntgen F, Lew AM, Shortman K and Wright MD. (2001) Molecular cloning of F4/80-like-receptor, a seven-span membrane protein expressed differentially by dendritic cell and monocyte-macrophage subpopulations. J. Immunol. 167: 3570-6 [PMID:11564768]

35. Caminschi I, Vandenabeele S, Sofi M, McKnight AJ, Ward N, Brodnicki TC, Toy T, Lahoud M, Maraskovsky E, Shortman K and Wright MD. (2006) Gene structure and transcript analysis of the human and mouse EGF-TM7 molecule, FIRE. DNA Seq 17: 8-14 [PMID:16753812]

36. Carr JC, Boese EA, Spanheimer PM, Dahdaleh FS, Martin M, Calva D, Schafer B, Thole DM, Braun T and O'Dorisio TM et al.. (2012) Differentiation of small bowel and pancreatic neuroendocrine tumors by geneexpression profiling. Surgery 152: 998-1007 [PMID:23158174]

37. Carroll N, Hughes L, McEntee G and Parle-McDermott A. (2012) Investigation of the molecular response to folate metabolism inhibition. J. Nutr. Biochem. 23: 1531-6 [PMID:22402366]

38. Carson-Walter EB, Watkins DN, Nanda A, Vogelstein B, Kinzler KW and St Croix B. (2001) Cell surface tumor endothelial markers are conserved in mice and humans. Cancer Res. 61: 6649-55 [PMID:11559528]

39. Carver EA, Hamann J, Olsen AS and Stubbs L. (1999) Physical mapping of EMR1 and CD97 in human Chromosome 19 and assignment of $\mathrm{Cd} 97$ to mouse Chromosome 8 suggest an ancient genomic duplication. Mamm. Genome 10: 1039-40 [PMID:10501980]

40. Chan YF, Jones FC, McConnell E, Bryk J, Bünger L and Tautz D. (2012) Parallel selection mapping using artificially selected mice reveals body weight control loci. Curr. Biol. 22: 794-800 [PMID:22445301]

41. Chang GW, Davies JQ, Stacey M, Yona S, Bowdish DM, Hamann J, Chen TC, Lin CY, Gordon S and Lin $\mathrm{HH}$. (2007) CD312, the human adhesion-GPCR EMR2, is differentially expressed during differentiation, maturation, and activation of myeloid cells. Biochem. Biophys. Res. Commun. 353: 133-8 
[PMID:17174274]

42. Chase A, Ernst T, Fiebig A, Collins A, Grand F, Erben P, Reiter A, Schreiber S and Cross NC. (2010) TFG, a target of chromosome translocations in lymphoma and soft tissue tumors, fuses to GPR128 in healthy individuals. Haematologica 95: 20-6 [PMID:19797732]

43. Chen G, Yang L, Begum S and Xu L. (2010) GPR56 is essential for testis development and male fertility in mice. Dev. Dyn. 239: 3358-67 [PMID:20981830]

44. Chen ML and Chen $\mathrm{CH}$. (2005) Microarray analysis of differentially expressed genes in rat frontal cortex under chronic risperidone treatment. Neuropsychopharmacology 30: 268-77 [PMID:15536490]

45. Chen TY, Hwang TL, Lin CY, Lin TN, Lai HY, Tsai WP and Lin HH. (2011) EMR2 receptor ligation modulates cytokine secretion profiles and cell survival of lipopolysaccharide-treated neutrophils. Chang Gung Med J 34: 468-77 [PMID:22035891]

46. Chidambaram A, Fillmore HL, Van Meter TE, Dumur Cl and Broaddus WC. (2012) Novel report of expression and function of CD97 in malignant gliomas: correlation with Wilms tumor 1 expression and glioma cell invasiveness. J. Neurosurg. 116: 843-53 [PMID:22313360]

47. Corbett AJ, Caminschi I, McKenzie BS, Brady JL, Wright MD, Mottram PL, Hogarth PM, Hodder AN, Zhan $\mathrm{Y}$ and Tarlinton DM et al.. (2005) Antigen delivery via two molecules on the CD8- dendritic cell subset induces humoral immunity in the absence of conventional "danger". Eur. J. Immunol. 35: 2815-25 [PMID:16143986]

48. Cork SM, Kaur B, Devi NS, Cooper L, Saltz JH, Sandberg EM, Kaluz S and Van Meir EG. (2012) A proprotein convertase/MMP-14 proteolytic cascade releases a novel $40 \mathrm{kDa}$ vasculostatin from tumor suppressor BAl1. Oncogene 31: 5144-52 [PMID:22330140]

49. Cortijo C, Gouzi M, Tissir F and Grapin-Botton A. (2012) Planar cell polarity controls pancreatic Beta cell differentiation and glucose homeostasis. Cell Rep 2: 1593-606 [PMID:23177622]

50. Cullen M, Elzarrad MK, Seaman S, Zudaire E, Stevens J, Yang MY, Li X, Chaudhary A, Xu L and Hilton MB et al.. (2011) GPR124, an orphan G protein-coupled receptor, is required for CNS-specific vascularization and establishment of the blood-brain barrier. Proc. Natl. Acad. Sci. U.S.A. 108: 5759-64 [PMID:21421844]

51. Curtin JA, Quint E, Tsipouri V, Arkell RM, Cattanach B, Copp AJ, Henderson DJ, Spurr N, Stanier P and Fisher EM et al.. (2003) Mutation of Celsr1 disrupts planar polarity of inner ear hair cells and causes severe neural tube defects in the mouse. Curr. Biol. 13: 1129-33 [PMID:12842012]

52. Das S, Owen KA, Ly KT, Park D, Black SG, Wilson JM, Sifri CD, Ravichandran KS, Ernst PB and Casanova JE. (2011) Brain angiogenesis inhibitor 1 (BAl1) is a pattern recognition receptor that mediates macrophage binding and engulfment of Gram-negative bacteria. Proc. Natl. Acad. Sci. U.S.A. 108: 213641 [PMID:21245295]

53. Davidson B, Stavnes HT, Risberg B, Nesland JM, Wohlschlaeger J, Yang Y, Shih leM and Wang TL. (2012) Gene expression signatures differentiate adenocarcinoma of lung and breast origin in effusions. Hum. Pathol. 43: 684-94 [PMID:21937081]

54. Davies B, Baumann C, Kirchhoff C, Ivell R, Nubbemeyer R, Habenicht UF, Theuring F and Gottwald U. (2004) Targeted deletion of the epididymal receptor HE6 results in fluid dysregulation and male infertility. Mol. Cell. Biol. 24: 8642-8 [PMID:15367682]

55. Davies B, Behnen M, Cappallo-Obermann H, Spiess AN, Theuring F and Kirchhoff C. (2007) Novel epididymis-specific mRNAs downregulated by HE6/Gpr64 receptor gene disruption. Mol. Reprod. Dev. 74: 539-53 [PMID:17034053]

56. Davies JQ, Lin HH, Stacey M, Yona S, Chang GW, Gordon S, Hamann J, Campo L, Han C and Chan Pet al.. (2011) Leukocyte adhesion-GPCR EMR2 is aberrantly expressed in human breast carcinomas and is associated with patient survival. Oncol. Rep. 25: 619-27 [PMID:21174063]

57. de Wilde J, Mohren R, van den Berg S, Boekschoten M, Dijk KW, de Groot P, Müller M, Mariman E and Smit E. (2008) Short-term high fat-feeding results in morphological and metabolic adaptations in the skeletal muscle of C57BL/6J mice. Physiol. Genomics 32: 360-9 [PMID:18042831]

58. Deaciuc IV, Arteel GE, Peng X, Hill DB and McClain CJ. (2004) Gene expression in the liver of rats fed 
alcohol by means of intragastric infusion. Alcoho/ 33: 17-30 [PMID:15353170]

59. DeRosse P, Lencz T, Burdick KE, Siris SG, Kane JM and Malhotra AK. (2008) The genetics of symptombased phenotypes: toward a molecular classification of schizophrenia. Schizophr Bull 34: 1047-53 [PMID:18628273]

60. Devenport D and Fuchs E. (2008) Planar polarization in embryonic epidermis orchestrates global asymmetric morphogenesis of hair follicles. Nat. Cell Biol. 10: 1257-68 [PMID:18849982]

61. Deák F, Liu X, Khvotchev M, Li G, Kavalali ET, Sugita S and Südhof TC. (2009) Alpha-latrotoxin stimulates a novel pathway of $\mathrm{Ca2+-dependent} \mathrm{synaptic} \mathrm{exocytosis} \mathrm{independent} \mathrm{of} \mathrm{the} \mathrm{classical} \mathrm{synaptic} \mathrm{fusion}$ machinery. J. Neurosci. 29: 8639-48 [PMID:19587270]

62. Dieterich LC, Mellberg S, Langenkamp E, Zhang L, Zieba A, Salomäki H, Teichert M, Huang H, Edqvist $\mathrm{PH}$ and Kraus T et al.. (2012) Transcriptional profiling of human glioblastoma vessels indicates a key role of VEGF-A and TGF $\beta 2$ in vascular abnormalization. J. Pathol. 228: 378-90 [PMID:22786655]

63. Diez-Roux G, Banfi S, Sultan M, Geffers L, Anand S, Rozado D, Magen A, Canidio E, Pagani M and Peluso I et al.. (2011) A high-resolution anatomical atlas of the transcriptome in the mouse embryo PLoS Biol. 9: e1000582 [PMID:21267068]

64. Dillman 3rd JF, Phillips CS, Dorsch LM, Croxton MD, Hege Al, Sylvester AJ, Moran TS and Sciuto AM. (2005) Genomic analysis of rodent pulmonary tissue following bis-(2-chloroethyl) sulfide exposure. Chem. Res. Toxicol. 18: 28-34 [PMID:15651846]

65. Duda DG, Sunamura M, Lozonschi L, Yokoyama T, Yatsuoka T, Motoi F, Horii A, Tani K, Asano S and Nakamura $Y$ et al.. (2002) Overexpression of the p53-inducible brain-specific angiogenesis inhibitor 1 suppresses efficiently tumour angiogenesis. Br. J. Cancer 86: 490-6 [PMID:11875720]

66. Ebermann I, Wiesen MH, Zrenner E, Lopez I, Pigeon R, Kohl S, Löwenheim H, Koenekoop RK and Bolz HJ. (2009) GPR98 mutations cause Usher syndrome type 2 in males. J. Med. Genet. 46: 277-80 [PMID:19357117]

67. Eichler W, Aust G and Hamann D. (1994) Characterization of an early activation-dependent antigen on lymphocytes defined by the monoclonal antibody BL-Ac(F2). Scand. J. Immunol. 39: 111-5 [PMID:8290889]

68. Eichler W, Hamann J and Aust G. (1997) Expression characteristics of the human CD97 antigen.Tissue Antigens 50: 429-38 [PMID:9389316]

69. Erkan M, Weis N, Pan Z, Schwager C, Samkharadze T, Jiang X, Wirkner U, Giese NA, Ansorge W, Debus J, Huber PE, Friess H, Abdollahi A and Kleeff J. (2010) Organ-, inflammation- and cancer specific transcriptional fingerprints of pancreatic and hepatic stellate cells. Mol. Cancer 9: 88 [PMID:20416094]

70. Ernst T, Chase A, Zoi K, Waghorn K, Hidalgo-Curtis C, Score J, Jones A, Grand F, Reiter A and Hochhaus A et al.. (2010) Transcription factor mutations in myelodysplastic/myeloproliferative neoplasms. Haematologica 95: 1473-80 [PMID:20421268]

71. Feng J, Xu Y, Wang M, Ruan Y, So KF, Tissir F, Goffinet A and Zhou L. (2012) A role for atypical cadherin Celsr3 in hippocampal maturation and connectivity. J. Neurosci. 32: 13729-43 [PMID:23035085]

72. Fenstermaker AG, Prasad AA, Bechara A, Adolfs Y, Tissir F, Goffinet A, Zou Y and Pasterkamp RJ. (2010) Wnt/planar cell polarity signaling controls the anterior-posterior organization of monoaminergic axons in the brainstem. J. Neurosci. 30: 16053-64 [PMID:21106844]

73. Fitzmaurice CJ, Brown LE, Kronin V and Jackson DC. (2000) The geometry of synthetic peptide-based immunogens affects the efficiency of $\mathrm{T}$ cell stimulation by professional antigen-presenting cells. Int. Immunol. 12: 527-35 [PMID:10744654]

74. Flicek P, Ahmed I, Amode MR, Barrell D, Beal K, Brent S, Carvalho-Silva D, Clapham P, Coates G and Fairley S et al.. (2013) Ensembl 2013. Nucleic Acids Res. 41: D48-55 [PMID:23203987]

75. Florian S, Sonneck K, Czerny M, Hennersdorf F, Hauswirth AW, Bühring HJ and Valent P. (2006) Detection of novel leukocyte differentiation antigens on basophils and mast cells by HLDA8 antibodies. Allergy 61: 1054-62 [PMID:16918507]

76. Foord SM, Jupe S and Holbrook J. (2002) Bioinformatics and type II G-protein-coupled receptors. Biochem. Soc. Trans. 30: 473-9 [PMID:12196118] 
77. Formstone CJ, Barclay J, Rees M and Little PF. (2000) Chromosomal localization of Celsr2 and Celsr3 in the mouse; Celsr3 is a candidate for the tippy (tip) lethal mutant on chromosome 9. Mamm. Genome 11: 392-4 [PMID:10790539]

78. Formstone CJ and Little PF. (2001) The flamingo-related mouse Celsr family (Celsr1-3) genes exhibit distinct patterns of expression during embryonic development. Mech Dev 109: 91-94 [PMID:11677057]

79. Formstone CJ, Moxon C, Murdoch J, Little P and Mason I. (2010) Basal enrichment within neuroepithelia suggests novel function(s) for Celsr1 protein. Mol. Cell. Neurosci. 44: 210-22 [PMID:20353824]

80. Fredriksson R, Gloriam DE, Höglund PJ, Lagerström MC and Schiöth HB. (2003) There exist at least 30 human G-protein-coupled receptors with long Ser/Thr-rich N-termini. Biochem. Biophys. Res. Commun. 301: 725-34 [PMID:12565841]

81. Fredriksson R, Lagerström MC, Höglund PJ and Schiöth HB. (2002) Novel human G protein-coupled receptors with long N-terminals containing GPS domains and Ser/Thr-rich regions. FEBS Lett. 531: 407-14 [PMID:12435584]

82. Fredriksson R, Lagerström MC, Lundin LG and Schiöth HB. (2003) The G-protein-coupled receptors in the human genome form five main families. Phylogenetic analysis, paralogon groups, and fingerprints. Mol. Pharmacol. 63: 1256-72 [PMID:12761335]

83. Galle J, Sittig D, Hanisch I, Wobus M, Wandel E, Loeffler M and Aust G. (2006) Individual cell-based models of tumor-environment interactions: Multiple effects of CD97 on tumor invasion. Am. J. Pathol.169: 1802-11 [PMID:17071601]

84. Galligan CL, Baig E, Bykerk V, Keystone EC and Fish EN. (2007) Distinctive gene expression signatures in rheumatoid arthritis synovial tissue fibroblast cells: correlates with disease activity. Genes Immun. 8: 480-91 [PMID:17568789]

85. Glaeser RM, Zilker A, Radermacher M, Gaub HE, Hartmann T and Baumeister W. (1991) Interfacial energies and surface-tension forces involved in the preparation of thin, flat crystals of biological macromolecules for high-resolution electron microscopy. J Microsc 161: 21-45 [PMID:2016735]

86. Goodyear R and Richardson G. (1999) The ankle-link antigen: an epitope sensitive to calcium chelation associated with the hair-cell surface and the calycal processes of photoreceptors. J. Neurosci. 19: 3761-72 [PMID:10234008]

87. Goodyear RJ and Richardson GP. (2003) A novel antigen sensitive to calcium chelation that is associated with the tip links and kinocilial links of sensory hair bundles. J. Neurosci. 23: 4878-87 [PMID:12832510]

88. Gordon S, Hamann J, Lin HH and Stacey M. (2011) F4/80 and the related adhesion-GPCRsEur. J. Immunol. 41: 2472-6 [PMID:21952799]

89. Gordon S, Lawson L, Rabinowitz S, Crocker PR, Morris L and Perry VH. (1992) Antigen markers of macrophage differentiation in murine tissues. Curr. Top. Microbiol. Immunol. 181: 1-37 [PMID:1424778]

90. Gordon S, Perry VH, Rabinowitz S, Chung LP and Rosen H. (1988) Plasma membrane receptors of the mononuclear phagocyte system. J. Cell Sci. Suppl. 9: 1-26 [PMID:3077135]

91. Gottwald U, Davies B, Fritsch M and Habenicht UF. (2006) New approaches for male fertility control: HE6 as an example of a putative target. Mol. Cell. Endocrinol. 250: 49-57 [PMID:16442214]

92. Gouveia LO, Sobral J, Vicente AM, Ferro JM and Oliveira SA. (2011) Replication of the CELSR1 association with ischemic stroke in a Portuguese case-control cohort. Atherosclerosis 217: 260-2 [PMID:21511255]

93. Gray JX, Haino M, Roth MJ, Maguire JE, Jensen PN, Yarme A, Stetler-Stevenson MA, Siebenlist U and Kelly K. (1996) CD97 is a processed, seven-transmembrane, heterodimeric receptor associated with inflammation. J. Immunol. 157: 5438-47 [PMID:8955192]

94. Gromova P, Ralea S, Lefort A, Libert F, Rubin BP, Erneux C and Vanderwinden JM. (2009) Kit K641E oncogene up-regulates Sprouty homolog 4 and trophoblast glycoprotein in interstitial cells of Cajal in a murine model of gastrointestinal stromal tumours. J. Cell. Mol. Med. 13: 1536-48 [PMID:19453770]

95. Gupte J, Swaminath G, Danao J, Tian H, Li Y and Wu X. (2012) Signaling property study of adhesion Gprotein-coupled receptors. FEBS Lett. 586: 1214-9 [PMID:22575658]

96. Györffy B, Surowiak P, Kiesslich O, Denkert C, Schäfer R, Dietel M and Lage H. (2006) Gene expression 
profiling of 30 cancer cell lines predicts resistance towards 11 anticancer drugs at clinically achieved concentrations. Int. J. Cancer 118: 1699-712 [PMID:16217747]

97. Hadjantonakis AK, Formstone CJ and Little PF. (1998) mCelsr1 is an evolutionarily conserved seven-pass transmembrane receptor and is expressed during mouse embryonic development. Mech. Dev. 78: 91-5 [PMID:9858697]

98. Hadjantonakis AK, Sheward WJ, Harmar AJ, de Galan L, Hoovers JM and Little PF. (1997) Celsr1, a neural-specific gene encoding an unusual seven-pass transmembrane receptor, maps to mouse chromosome 15 and human chromosome 22qter. Genomics 45: 97-104 [PMID:9339365]

99. Haitina T, Olsson F, Stephansson O, Alsiö J, Roman E, Ebendal T, Schiöth HB and Fredriksson R. (2008) Expression profile of the entire family of Adhesion $G$ protein-coupled receptors in mouse and rat. BMC Neurosci 9: 43 [PMID:18445277]

100. Hamann J, Aust G, Araç D, Engel FB, Formstone C, Fredriksson R, Hall RA, Harty BL, Kirchhoff $C$ and Knapp B et al.. (2015) International Union of Basic and Clinical Pharmacology. XCIV. Adhesion G proteincoupled receptors. Pharmacol. Rev. 67: 338-67 [PMID:25713288]

101. Hamann J, Koning N, Pouwels W, Ulfman LH, van Eijk M, Stacey M, Lin HH, Gordon S and Kwakkenbos MJ. (2007) EMR1, the human homolog of F4/80, is an eosinophil-specific receptor. Eur. J. Immunol. 37: 2797-802 [PMID:17823986]

102. Hamann J, Kwakkenbos MJ, de Jong EC, Heus H, Olsen AS and van Lier RA. (2003) Inactivation of the EGF-TM7 receptor EMR4 after the Pan-Homo divergence. Eur J Immuno/ 33: 1365-1371 [PMID:12731063]

103. Hamann J, Stortelers C, Kiss-Toth E, Vogel B, Eichler W and van Lier RA. (1998) Characterization of the CD55 (DAF)-binding site on the seven-span transmembrane receptor CD97. Eur. J. Immunol. 28: 1701-7 [PMID:9603477]

104. Hamann J, van Zeventer C, Bijl A, Molenaar C, Tesselaar K and van Lier RA. (2000) Molecular cloning and characterization of mouse CD97. Int. Immunol. 12: 439-48 [PMID:10744645]

105. Hamann J, Vogel B, van Schijndel GM and van Lier RA. (1996) The seven-span transmembrane receptor CD97 has a cellular ligand (CD55, DAF). J. Exp. Med. 184: 1185-9 [PMID:9064337]

106. Hamann J, Wishaupt JO, van Lier RA, Smeets TJ, Breedveld FC and Tak PP. (1999) Expression of the activation antigen CD97 and its ligand CD55 in rheumatoid synovial tissue. Arthritis Rheum. 42: 650-8 [PMID:10211878]

107. Han SL, Xu C, Wu XL, Li JL, Liu Z and Zeng QQ. (2010) The impact of expressions of CD97 and its ligand CD55 at the invasion front on prognosis of rectal adenocarcinoma. Int $J$ Colorectal Dis 25: 695-702 [PMID:20339853]

108. Hancock DB, Eijgelsheim M, Wilk JB, Gharib SA, Loehr LR, Marciante KD, Franceschini N, van Durme YM, Chen TH and Barr RG et al.. (2010) Meta-analyses of genome-wide association studies identify multiple loci associated with pulmonary function. Nat. Genet. 42: 45-52 [PMID:20010835]

109. Hardcastle J, Kurozumi K, Dmitrieva N, Sayers MP, Ahmad S, Waterman P, Weissleder R, Chiocca EA and Kaur B. (2010) Enhanced antitumor efficacy of vasculostatin (Vstat120) expressing oncolytic HSV-1. Mol. Ther. 18: 285-94 [PMID:19844198]

110. Harkensee C, Oka A, Onizuka M, Middleton PG, Inoko H, Nakaoka H, Gennery AR, Ando K, Morishima Y and Japan Marrow Donor Programme (JMDP). (2013) Microsatellite scanning of the immunogenome associates MAPK14 and ELTD1 with graft-versus-host disease in hematopoietic stem cell transplantation. Immunogenetics 65: 417-27 [PMID:23474535]

111. Harvey RC, Mullighan CG, Wang X, Dobbin KK, Davidson GS, Bedrick EJ, Chen IM, Atlas SR, Kang H and $\mathrm{Ar} \mathrm{K}$ et al.. (2010) Identification of novel cluster groups in pediatric high-risk B-precursor acute lymphoblastic leukemia with gene expression profiling: correlation with genome-wide DNA copy number alterations, clinical characteristics, and outcome. Blood 116: 4874-84 [PMID:20699438]

112. He L, Sun Y, Patrakka J, Mostad P, Norlin J, Xiao Z, Andrae J, Tryggvason K, Samuelsson T and Betsholtz $C$ et al.. (2007) Glomerulus-specific mRNA transcripts and proteins identified through kidney expressed sequence tag database analysis. Kidney Int. 71: 889-900 [PMID:17332733]

113. He Z, Kokkinaki M, Jiang J, Dobrinski I and Dym M. (2010) Isolation, characterization, and culture of 
human spermatogonia. Biol. Reprod. 82: 363-72 [PMID:19846602]

114. He Z, Kokkinaki M, Jiang J, Zeng W, Dobrinski I and Dym M. (2012) Isolation of human male germ-line stem cells using enzymatic digestion and magnetic-activated cell sorting. Methods Mol. Biol. 825: 45-57 [PMID:22144235]

115. Hermle T, Guida MC, Beck S, Helmstädter S and Simons M. (2013) Drosophila ATP6AP2/VhaPRR functions both as a novel planar cell polarity core protein and a regulator of endosomal trafficking. EMBO J. 32: 245-59 [PMID:23292348]

116. Hilgert N, Kahrizi K, Dieltjens N, Bazazzadegan N, Najmabadi H, Smith RJ and Van Camp G. (2009) A large deletion in GPR98 causes type IIC Usher syndrome in male and female members of an Iranian family. J. Med. Genet. 46: 272-6 [PMID:19357116]

117. Hoang-Vu C, Bull K, Schwarz I, Krause G, Schmutzler C, Aust G, Köhrle J and Dralle H. (1999) Regulation of CD97 protein in thyroid carcinoma. J. Clin. Endocrinol. Metab. 84: 1104-9 [PMID:10084602]

118. Hoek RM, de Launay D, Kop EN, Yilmaz-Elis AS, Lin F, Reedquist KA, Verbeek JS, Medof ME, Tak PP and Hamann J. (2010) Deletion of either CD55 or CD97 ameliorates arthritis in mouse models. Arthritis Rheum. 62: 1036-42 [PMID:20131275]

119. Homma S, Shimada T, Hikake T and Yaginuma H. (2009) Expression pattern of LRR and Ig domaincontaining protein (LRRIG protein) in the early mouse embryo. Gene Expr. Patterns 9: 1-26 [PMID:18848646]

120. Huang Y, Fan J, Yang J and Zhu GZ. (2008) Characterization of GPR56 protein and its suppressed expression in human pancreatic cancer cells. Mol. Cell. Biochem. 308: 133-9 [PMID:17932623]

121. Huang YS, Chiang NY, Hu CH, Hsiao CC, Cheng KF, Tsai WP, Yona S, Stacey M, Gordon S and Chang GW et al.. (2012) Activation of myeloid cell-specific adhesion class G protein-coupled receptor EMR2 via ligation-induced translocation and interaction of receptor subunits in lipid raft microdomains. Mol. Cell. Biol. 32: 1408-20 [PMID:22310662]

122. Ichtchenko K, Bittner MA, Krasnoperov V, Little AR, Chepurny O, Holz RW and Petrenko AG. (1999) A novel ubiquitously expressed alpha-latrotoxin receptor is a member of the CIRL family of G-proteincoupled receptors. J. Biol. Chem. 274: 5491-8 [PMID:10026162]

123. Ichtchenko K, Khvotchev M, Kiyatkin N, Simpson L, Sugita S and Südhof TC. (1998) alpha-latrotoxin action probed with recombinant toxin: receptors recruit alpha-latrotoxin but do not transduce an exocytotic signal. EMBO J. 17: 6188-99 [PMID:9799228]

124. Iguchi T, Sakata K, Yoshizaki K, Tago K, Mizuno N and Itoh H. (2008) Orphan G protein-coupled receptor GPR56 regulates neural progenitor cell migration via a $G$ alpha $12 / 13$ and Rho pathway. J. Biol. Chem.

283: 14469-78 [PMID:18378689]

125. Ishikawa K, Nagase T, Suyama M, Miyajima N, Tanaka A, Kotani H, Nomura N and Ohara O. (1998) Prediction of the coding sequences of unidentified human genes. $X$. The complete sequences of 100 new cDNA clones from brain which can code for large proteins in vitro. DNA Res. 5: 169-76 [PMID:9734811]

126. Ito J, Ito M, Nambu H, Fujikawa T, Tanaka K, Iwaasa H and Tokita S. (2009) Anatomical and histological profiling of orphan G-protein-coupled receptor expression in gastrointestinal tract of C57BL/6J mice. Cell Tissue Res. 338: 257-69 [PMID:19763624]

127. Izadyar F, Wong J, Maki C, Pacchiarotti J, Ramos T, Howerton K, Yuen C, Greilach S, Zhao HH and Chow $M$ et al.. (2011) Identification and characterization of repopulating spermatogonial stem cells from the adult human testis. Hum. Reprod. 26: 1296-306 [PMID:21349855]

128. Jacobson SG, Cideciyan AV, Aleman TS, Sumaroka A, Roman AJ, Gardner LM, Prosser HM, Mishra M, Bech-Hansen NT, Herrera W, Schwartz SB, Liu XZ, Kimberling WJ, Steel KP and Williams DS. (2008) Usher syndromes due to MYO7A, PCDH15, USH2A or GPR98 mutations share retinal disease mechanism. Hum. Mol. Genet. 17: 2405-15 [PMID:18463160]

129. Jaspars LH, Vos W, Aust G, Van Lier RA and Hamann J. (2001) Tissue distribution of the human CD97 EGF-TM7 receptor. Tissue Antigens 57: 325-31 [PMID:11380941]

130. Jeong BC, Kim MY, Lee JH, Kee HJ, Kho DH, Han KE, Qian YR, Kim JK and Kim KK. (2006) Brainspecific angiogenesis inhibitor 2 regulates VEGF through GABP that acts as a transcriptional repressor. 
FEBS Lett. 580: 669-76 [PMID:16412436]

131. Jeong SJ, Luo R, Li S, Strokes N and Piao X. (2012) Characterization of G protein-coupled receptor 56 protein expression in the mouse developing neocortex. J. Comp. Neurol. 520: 2930-40 [PMID:22351047]

132. Kamesh N, Aradhyam GK and Manoj N. (2008) The repertoire of G protein-coupled receptors in the sea squirt Ciona intestinalis. BMC Evol. Biol. 8: 129 [PMID:18452600]

133. Kan Z, Jaiswal BS, Stinson J, Janakiraman V, Bhatt D, Stern HM, Yue P, Haverty PM, Bourgon R, Zheng J, Moorhead M, Chaudhuri S, Tomsho LP, Peters BA, Pujara K, Cordes S, Davis DP, Carlton VE, Yuan W, Li L, Wang W, Eigenbrot C, Kaminker JS, Eberhard DA, Waring P, Schuster SC, Modrusan Z, Zhang Z, Stokoe D, de Sauvage FJ, Faham M and Seshagiri S. (2010) Diverse somatic mutation patterns and pathway alterations in human cancers. Nature 466: 869-73 [PMID:20668451]

134. Kane AJ, Sughrue ME, Rutkowski MJ, Phillips JJ and Parsa AT. (2010) EMR-3: a potential mediator of invasive phenotypic variation in glioblastoma and novel therapeutic target. Neuroreport 21: 1018-22 [PMID:20827226]

135. Kang X, Xiao X, Harata M, Bai Y, Nakazaki Y, Soda Y, Kurita R, Tanaka T, Komine F, Izawa K, Kunisaki R, Setoyama M, Nishimori H, Natsume A, Sunamura M, Lozonshi L, Saitoh I, Tokino T, Asano S, Nakamura $Y$ and Tani K. (2006) Antiangiogenic activity of BAl1 in vivo: implications for gene therapy of human glioblastomas. Cancer Gene Ther. 13: 385-92 [PMID:16244591]

136. Kaur B, Cork SM, Sandberg EM, Devi NS, Zhang Z, Klenotic PA, Febbraio M, Shim H, Mao H, TuckerBurden C, Silverstein RL, Brat DJ, Olson JJ and Van Meir EG. (2009) Vasculostatin inhibits intracranial glioma growth and negatively regulates in vivo angiogenesis through a CD36-dependent mechanism. Cancer Res. 69: 1212-20 [PMID:19176395]

137. Ke N, Sundaram R, Liu G, Chionis J, Fan W, Rogers C, Awad T, Grifman M, Yu D and Wong-Staal Fet al.. (2007) Orphan G protein-coupled receptor GPR56 plays a role in cell transformation and tumorigenesis involving the cell adhesion pathway. Mol. Cancer Ther. 6: 1840-50 [PMID:17575113]

138. Kee HJ, Ahn KY, Choi KC, Won Song J, Heo T, Jung S, Kim JK, Bae CS and Kim KK. (2004) Expression of brain-specific angiogenesis inhibitor 3 (BAI3) in normal brain and implications for BAl3 in ischemiainduced brain angiogenesis and malignant glioma. FEBS Lett. 569: 307-16 [PMID:15225653]

139. Kee HJ, Koh JT, Kim MY, Ahn KY, Kim JK, Bae CS, Park SS and Kim KK. (2002) Expression of brainspecific angiogenesis inhibitor 2 (BAI2) in normal and ischemic brain: involvement of BAI2 in the ischemiainduced brain angiogenesis. J. Cereb. Blood Flow Metab. 22: 1054-67 [PMID:12218411]

140. Kim JJ, Park YM, Baik KH, Choi HY, Yang GS, Koh I, Hwang JA, Lee J, Lee YS and Rhee Het al.. (2012) Exome sequencing and subsequent association studies identify five amino acid-altering variants influencing human height. Hum. Genet. 131: 471-8 [PMID:21959382]

141. Kim YK, Moon S, Hwang MY, Kim DJ, Oh JH, Kim YJ, Han BG, Lee JY and Kim BJ. (2013) Gene-based copy number variation study reveals a microdeletion at 12q24 that influences height in the Korean population. Genomics 101: 134-8 [PMID:23147675]

142. Kirchhoff C, Osterhoff $C$ and Samalecos A. (2008) HE6/GPR64 adhesion receptor co-localizes with apical and subapical F-actin scaffold in male excurrent duct epithelia. Reproduction 136: 235-45 [PMID:18469038]

143. Kobayashi A, Donaldson DS, Kanaya T, Fukuda S, Baillie JK, Freeman TC, Ohno H, Williams IR and Mabbott NA. (2012) Identification of novel genes selectively expressed in the follicle-associated epithelium from the meta-analysis of transcriptomics data from multiple mouse cell and tissue populations. DNA Res. 19: 407-22 [PMID:22991451]

144. Koh JT, Kook H, Kee HJ, Seo YW, Jeong BC, Lee JH, Kim MY, Yoon KC, Jung S and Kim KK. (2004) Extracellular fragment of brain-specific angiogenesis inhibitor 1 suppresses endothelial cell proliferation by blocking alphavbeta5 integrin. Exp. Cell Res. 294: 172-84 [PMID:14980512]

145. Koh JT, Lee ZH, Ahn KY, Kim JK, Bae CS, Kim HH, Kee HJ and Kim KK. (2001) Characterization of mouse brain-specific angiogenesis inhibitor 1 (BAl1) and phytanoyl-CoA alpha-hydroxylase-associated protein 1, a novel BAl1-binding protein. Brain Res. Mol. Brain Res. 87: 223-37 [PMID:11245925]

146. Koirala $S$ and Corfas $G$. (2010) Identification of novel glial genes by single-cell transcriptional profiling of 
Bergmann glial cells from mouse cerebellum. PLoS ONE 5: e9198 [PMID:20169146]

147. Koirala S, Jin Z, Piao X and Corfas G. (2009) GPR56-regulated granule cell adhesion is essential for rostral cerebellar development. J. Neurosci. 29: 7439-49 [PMID:19515912]

148. Kop EN, Kwakkenbos MJ, Teske GJ, Kraan MC, Smeets TJ, Stacey M, Lin HH, Tak PP and Hamann J. (2005) Identification of the epidermal growth factor-TM7 receptor EMR2 and its ligand dermatan sulfate in rheumatoid synovial tissue. Arthritis Rheum. 52: 442-50 [PMID:15693006]

149. Kop EN, Matmati M, Pouwels W, Leclercq G, Tak PP and Hamann J. (2009) Differential expression of CD97 on human lymphocyte subsets and limited effect of CD97 antibodies on allogeneic T-cell stimulation. Immunol. Lett. 123: 160-8 [PMID:19428565]

150. Kou I, Takahashi Y, Johnson TA, Takahashi A, Guo L, Dai J, Qiu X, Sharma S, Takimoto A and Ogura Yet al.. (2013) Genetic variants in GPR126 are associated with adolescent idiopathic scoliosisNat. Genet. 45: 676-679 [PMID:23666238]

151. Kraja AT, Borecki IB, Tsai MY, Ordovas JM, Hopkins PN, Lai CQ, Frazier-Wood AC, Straka RJ, Hixson JE and Province MA et al.. (2013) Genetic analysis of 16 NMR-lipoprotein fractions in humans, the GOLDN study. Lipids 48: 155-65 [PMID:23192668]

152. Krasnoperov V, Lu Y, Buryanovsky L, Neubert TA, Ichtchenko K and Petrenko AG. (2002) Posttranslational proteolytic processing of the calcium-independent receptor of alpha-latrotoxin (CIRL), a natural chimera of the cell adhesion protein and the G protein-coupled receptor. Role of the G proteincoupled receptor proteolysis site (GPS) motif. J. Biol. Chem. 277: 46518-26 [PMID:12270923]

153. Krasnoperov VG, Bittner MA, Beavis R, Kuang Y, Salnikow KV, Chepurny OG, Little AR, Plotnikov AN, Wu $\mathrm{D}$ and Holz RW et al.. (1997) alpha-Latrotoxin stimulates exocytosis by the interaction with a neuronal Gprotein-coupled receptor. Neuron 18: 925-37 [PMID:9208860]

154. Kudo S, Konda R, Obara W, Kudo D, Tani K, Nakamura Y and Fujioka T. (2007) Inhibition of tumor growth through suppression of angiogenesis by brain-specific angiogenesis inhibitor 1 gene transfer in murine renal cell carcinoma. Oncol. Rep. 18: 785-91 [PMID:17786337]

155. Kuhnert F, Mancuso MR, Shamloo A, Wang HT, Choksi V, Florek M, Su H, Fruttiger M, Young WL and Heilshorn SC et al.. (2010) Essential regulation of CNS angiogenesis by the orphan G protein-coupled receptor GPR124. Science 330: 985-9 [PMID:21071672]

156. Kwakkenbos MJ, Chang GW, Lin HH, Pouwels W, de Jong EC, van Lier RA, Gordon S and Hamann J. (2002) The human EGF-TM7 family member EMR2 is a heterodimeric receptor expressed on myeloid cells. J. Leukoc. Biol. 71: 854-62 [PMID:11994511]

157. Kwakkenbos MJ, Kop EN, Stacey M, Matmati M, Gordon S, Lin HH and Hamann J. (2004) The EGF-TM7 family: a postgenomic view. Immunogenetics 55: 655-66 [PMID:14647991]

158. Kwakkenbos MJ, Matmati M, Madsen O, Pouwels W, Wang Y, Bontrop RE, Heidt PJ, Hoek RM and Hamann J. (2006) An unusual mode of concerted evolution of the EGF-TM7 receptor chimera EMR2. FASEB J. 20: 2582-4 [PMID:17068111]

159. Kwakkenbos MJ, Pouwels W, Matmati M, Stacey M, Lin HH, Gordon S, van Lier RA and Hamann J. (2005) Expression of the largest CD97 and EMR2 isoforms on leukocytes facilitates a specific interaction with chondroitin sulfate on B cells. J. Leukoc. Biol. 77: 112-9 [PMID:15498814]

160. Labbe A, Liu A, Atherton J, Gizenko N, Fortier MÈ, Sengupta SM and Ridha J. (2012) Refining psychiatric phenotypes for response to treatment: contribution of LPHN3 in ADHD. Am. J. Med. Genet. $B$ Neuropsychiatr. Genet. 159B: 776-85 [PMID:22851411]

161. Lagerström MC, Rabe N, Haitina T, Kalnina I, Hellström AR, Klovins J, Kullander K and Schiöth HB. (2007) The evolutionary history and tissue mapping of GPR123: specific CNS expression pattern predominantly in thalamic nuclei and regions containing large pyramidal cells. J. Neurochem. 100: 1129-42 [PMID:17212699]

162. Lajus S, Vacher P, Huber D, Dubois M, Benassy MN, Ushkaryov Y and Lang J. (2006) Alpha-latrotoxin induces exocytosis by inhibition of voltage-dependent $\mathrm{K}+$ channels and by stimulation of L-type Ca2+ channels via latrophilin in beta-cells. J. Biol. Chem. 281: 5522-31 [PMID:16301314]

163. Le Quesne Stabej P, Saihan Z, Rangesh N, Steele-Stallard HB, Ambrose J, Coffey A, Emmerson J, 
Haralambous E, Hughes $Y$ and Steel KP et al.. (2012) Comprehensive sequence analysis of nine Usher syndrome genes in the UK National Collaborative Usher Study. J. Med. Genet. 49: 27-36 [PMID:22135276]

164. Lee J, Hever A, Willhite D, Zlotnik A and Hevezi P. (2005) Effects of RNA degradation on gene expression analysis of human postmortem tissues. FASEB J.19: 1356-8 [PMID:15955843]

165. Lee KT, Byun MJ, Kang KS, Park EW, Lee SH, Cho S, Kim H, Kim KW, Lee T and Park JEet al.. (2011) Neuronal genes for subcutaneous fat thickness in human and pig are identified by local genomic sequencing and combined SNP association study. PLOS ONE 6: e16356 [PMID:21311593]

166. Leja J, Essaghir A, Essand M, Wester K, Oberg K, Tötterman TH, Lloyd R, Vasmatzis G, Demoulin JB and Giandomenico V. (2009) Novel markers for enterochromaffin cells and gastrointestinal neuroendocrine carcinomas. Mod. Pathol. 22: 261-72 [PMID:18953328]

167. Lelianova VG, Davletov BA, Sterling A, Rahman MA, Grishin EV, Totty NF and Ushkaryov YA. (1997) Alpha-latrotoxin receptor, latrophilin, is a novel member of the secretin family of $G$ protein-coupled receptors. J. Biol. Chem. 272: 21504-8 [PMID:9261169]

168. Lelyanova VG, Thomson D, Ribchester RR, Tonevitsky EA and Ushkaryov YA. (2009) Activation of alphalatrotoxin receptors in neuromuscular synapses leads to a prolonged splash acetylcholine release. Bull. Exp. Biol. Med. 147: 701-3 [PMID:19902061]

169. Lennon G, Auffray C, Polymeropoulos M and Soares MB. (1996) The I.M.A.G.E. Consortium: an integrated molecular analysis of genomes and their expression. Genomics 33: 151-2 [PMID:8617505]

170. Lettre G, Jackson AU, Gieger C, Schumacher FR, Berndt SI, Sanna S, Eyheramendy S, Voight BF, Butler $\mathrm{JL}$ and Guiducci $\mathrm{C}$ et al.. (2008) Identification of ten loci associated with height highlights new biological pathways in human growth. Nat. Genet. 40: 584-91 [PMID:18391950]

171. Li S, Jin Z, Koirala S, Bu L, Xu L, Hynes RO, Walsh CA, Corfas G and Piao X. (2008) GPR56 regulates pial basement membrane integrity and cortical lamination. J. Neurosci. 28: 5817-26 [PMID:18509043]

172. Lin HH, Chang GW, Davies JQ, Stacey M, Harris J and Gordon S. (2004) Autocatalytic cleavage of the EMR2 receptor occurs at a conserved G protein-coupled receptor proteolytic site motif. J. Biol. Chem. 279: 31823-32 [PMID:15150276]

173. Lin HH, Faunce DE, Stacey M, Terajewicz A, Nakamura T, Zhang-Hoover J, Kerley M, Mucenski ML, Gordon S and Stein-Streilein J. (2005) The macrophage F4/80 receptor is required for the induction of antigen-specific efferent regulatory T cells in peripheral tolerance. J. Exp. Med. 201: 1615-25 [PMID:15883173]

174. Lin HH, Stacey M, Hamann J, Gordon S and McKnight AJ. (2000) Human EMR2, a novel EGF-TM7 molecule on chromosome 19p13.1, is closely related to CD97. Genomics 67: 188-200 [PMID:10903844]

175. Lin HH, Stacey M, Saxby C, Knott V, Chaudhry Y, Evans D, Gordon S, McKnight AJ, Handford P and Lea S. (2001) Molecular analysis of the epidermal growth factor-like short consensus repeat domain-mediated protein-protein interactions: dissection of the CD97-CD55 complex. J. Biol. Chem. 276: 24160-9 [PMID:11297558]

176. Lin HH, Stacey M, Stein-Streilein J and Gordon S. (2010) F4/80: the macrophage-specific adhesion-GPCR and its role in immunoregulation. Adv. Exp. Med. Biol. 706: 149-56 [PMID:21618834]

177. Liu M, Parker RM, Darby K, Eyre HJ, Copeland NG, Crawford J, Gilbert DJ, Sutherland GR, Jenkins NA and Herzog H. (1999) GPR56, a novel secretin-like human G-protein-coupled receptor gene. Genomics 55: 296-305 [PMID:10049584]

178. Loberg RD, Wojno KJ, Day LL and Pienta KJ. (2005) Analysis of membrane-bound complement regulatory proteins in prostate cancer. Urology 66: 1321-6 [PMID:16360477]

179. LopezJimenez ND, Sainz E, Cavenagh MM, Cruz-Ithier MA, Blackwood CA, Battey JF and Sullivan SL. (2005) Two novel genes, Gpr113, which encodes a family 2 G-protein-coupled receptor, and Trcg1, are selectively expressed in taste receptor cells. Genomics 85: 472-82 [PMID:15780750]

180. Lum AM, Wang BB, Beck-Engeser GB, Li L, Channa N and Wabl M. (2010) Orphan receptor GPR110, an oncogene overexpressed in lung and prostate cancer. BMC Cancer 10: 40 [PMID:20149256]

181. Luo R, Jeong SJ, Jin Z, Strokes N, Li S and Piao X. (2011) G protein-coupled receptor 56 and collagen III, a receptor-ligand pair, regulates cortical development and lamination. Proc. Natl. Acad. Sci. U.S.A. 108: 
12925-30 [PMID:21768377]

182. Luo R, Yang HM, Jin Z, Halley DJ, Chang BS, MacPherson L, Brueton L and Piao X. (2011) A novel GPR56 mutation causes bilateral frontoparietal polymicrogyria. Pediatr. Neurol. 45: 49-53 [PMID:21723461]

183. Maerker T, van Wijk E, Overlack N, Kersten FF, McGee J, Goldmann T, Sehn E, Roepman R, Walsh EJ and Kremer $\mathrm{H}$ et al.. (2008) A novel Usher protein network at the periciliary reloading point between molecular transport machineries in vertebrate photoreceptor cells. Hum. Mol. Genet. 17: 71-86 [PMID:17906286]

184. Mah MW, Priel IE, Humen DP, Brown NE and Sproule BJ. (1989) Idiopathic pulmonary hemosiderosis, complete heart block and celiac disease. Can J Cardiol 5: 191-4 [PMID:2731063]

185. Malm E, Ponjavic V, Möller C, Kimberling WJ and Andréasson S. (2011) Phenotypes in defined genotypes including siblings with Usher syndrome. Ophthalmic Genet. 32: 65-74 [PMID:21174530]

186. Marroni F, Pfeufer A, Aulchenko YS, Franklin CS, Isaacs A, Pichler I, Wild SH, Oostra BA, Wright AF, Campbell H, Witteman JC, Kääb S, Hicks AA, Gyllensten U, Rudan I, Meitinger T, Pattaro C, van Duijn CM, Wilson JF, Pramstaller PP and EUROSPAN Consortium. (2009) A genome-wide association scan of RR and QT interval duration in 3 European genetically isolated populations: the EUROSPAN project. Circ Cardiovasc Genet 2: 322-8 [PMID:20031603]

187. Martinez AF, Muenke M and Arcos-Burgos M. (2011) From the black widow spider to human behavior: Latrophilins, a relatively unknown class of $G$ protein-coupled receptors, are implicated in psychiatric disorders. Am. J. Med. Genet. B Neuropsychiatr. Genet. 156B: 1-10 [PMID:21184579]

188. Martinez-Pomares L, Platt N, McKnight AJ, da Silva RP and Gordon S. (1996) Macrophage membrane molecules: markers of tissue differentiation and heterogeneity. Immunobiology 195: 407-16 [PMID:8933147]

189. Martínez-Poveda B, García-Vilas JA, Cárdenas C, Melgarejo E, Quesada AR and Medina MA. (2013) The brominated compound aeroplysinin-1 inhibits proliferation and the expression of key pro- inflammatory molecules in human endothelial and monocyte cells. PLoS ONE 8: e55203 [PMID:23383109]

190. Matmati M, Pouwels W, van Bruggen R, Jansen M, Hoek RM, Verhoeven AJ and Hamann J. (2007) The human EGF-TM7 receptor EMR3 is a marker for mature granulocytes. J. Leukoc. Biol. 81: 440-8 [PMID:17108056]

191. Matsushita H, Lelianova VG and Ushkaryov YA. (1999) The latrophilin family: multiply spliced G proteincoupled receptors with differential tissue distribution. FEBS Lett. 443: 348-52 [PMID:10025961]

192. McGarry MP and Stewart CC. (1991) Murine eosinophil granulocytes bind the murine macrophagemonocyte specific monoclonal antibody F4/80. J. Leukoc. Biol. 50: 471-8 [PMID:1721083]

193. McGee J, Goodyear RJ, McMillan DR, Stauffer EA, Holt JR, Locke KG, Birch DG, Legan PK, White PC and Walsh EJ et al.. (2006) The very large G-protein-coupled receptor VLGR1: a component of the ankle link complex required for the normal development of auditory hair bundles. J. Neurosci. 26: 6543-53 [PMID:16775142]

194. McKnight AJ and Gordon S. (1998) The EGF-TM7 family: unusual structures at the leukocyte surface $J$. Leukoc. Biol. 63: 271-80 [PMID:9500513]

195. McKnight AJ, Macfarlane AJ, Dri P, Turley L, Willis AC and Gordon S. (1996) Molecular cloning of F4/80, a murine macrophage-restricted cell surface glycoprotein with homology to the G-protein-linked transmembrane 7 hormone receptor family. J. Biol. Chem. 271: 486-9 [PMID:8550607]

196. McKnight AJ, Macfarlane AJ, Seldin MF and Gordon S. (1997) Chromosome mapping of the Emr1 gene. Mamm. Genome 8: 946 [PMID:9383301]

197. McMillan DR, Kayes-Wandover KM, Richardson JA and White PC. (2002) Very large G protein-coupled receptor-1, the largest known cell surface protein, is highly expressed in the developing central nervous system. J. Biol. Chem. 277: 785-92 [PMID:11606593]

198. McMillan DR and White PC. (2004) Loss of the transmembrane and cytoplasmic domains of the very large G-protein-coupled receptor-1 (VLGR1 or Mass1) causes audiogenic seizures in mice. Mol. Cell. Neurosci.

26: $322-9$ [PMID:15207856] 
199. McMillan DR and White PC. (2010) Studies on the very large G protein-coupled receptor: from initial discovery to determining its role in sensorineural deafness in higher animals. Adv. Exp. Med. Biol. 706: 7686 [PMID:21618827]

200. Michalski N, Michel V, Bahloul A, Lefèvre G, Barral J, Yagi H, Chardenoux S, Weil D, Martin P and Hardelin JP et al.. (2007) Molecular characterization of the ankle-link complex in cochlear hair cells and its role in the hair bundle functioning. J. Neurosci. 27: 6478-88 [PMID:17567809]

201. Miller SJ, Jessen WJ, Mehta T, Hardiman A, Sites E, Kaiser S, Jegga AG, Li H, Upadhyaya M and Giovannini $\mathrm{M}$ et al.. (2009) Integrative genomic analyses of neurofibromatosis tumours identify SOX9 as a biomarker and survival gene. EMBO Mol Med 1: 236-48 [PMID:20049725]

202. Monk KR, Naylor SG, Glenn TD, Mercurio S, Perlin JR, Dominguez C, Moens CB and Talbot WS. (2009) A $G$ protein-coupled receptor is essential for Schwann cells to initiate myelination. Science 325: 1402-5 [PMID:19745155]

203. Monk KR, Oshima K, Jörs S, Heller S and Talbot WS. (2011) Gpr126 is essential for peripheral nerve development and myelination in mammals. Development 138: 2673-80 [PMID:21613327]

204. Mori K, Kanemura Y, Fujikawa H, Nakano A, Ikemoto H, Ozaki I, Matsumoto T, Tamura K, Yokota M and Arita N. (2002) Brain-specific angiogenesis inhibitor 1 (BAl1) is expressed in human cerebral neuronal cells. Neurosci. Res. 43: 69-74 [PMID:12074842]

205. Moriguchi T, Haraguchi K, Ueda N, Okada M, Furuya T and Akiyama T. (2004) DREG, a developmentally regulated $\mathrm{G}$ protein-coupled receptor containing two conserved proteolytic cleavage sites. Genes Cells 9: 549-60 [PMID:15189448]

206. Mustafa T, Klonisch T, Hombach-Klonisch S, Kehlen A, Schmutzler C, Koehrle J, Gimm O, Dralle H and Hoang-Vu C. (2004) Expression of CD97 and CD55 in human medullary thyroid carcinomas. Int. J. Oncol. 24: 285-94 [PMID:14719104]

207. Naciff JM, Hess KA, Overmann GJ, Torontali SM, Carr GJ, Tiesman JP, Foertsch LM, Richardson BD, Martinez JE and Daston GP. (2005) Gene expression changes induced in the testis by transplacental exposure to high and low doses of 17 alpha\}-ethynyl estradiol, genistein, or bisphenol A. Toxicol. Sci. 86 : 396-416 [PMID:15901920]

208. Naciff JM, Jump ML, Torontali SM, Carr GJ, Tiesman JP, Overmann GJ and Daston GP. (2002) Gene expression profile induced by 17 alpha-ethynyl estradiol, bisphenol $A$, and genistein in the developing female reproductive system of the rat. Toxicol. Sci. 68: 184-99 [PMID:12075121]

209. Nagase T, Ishikawa K, Suyama M, Kikuno R, Miyajima N, Tanaka A, Kotani H, Nomura N and Ohara O. (1998) Prediction of the coding sequences of unidentified human genes. XI. The complete sequences of 100 new cDNA clones from brain which code for large proteins in vitro. DNA Res 5: 277-286 [PMID:9872452]

210. Nagase $T$, Seki N, Ishikawa K, Ohira M, Kawarabayasi $Y$, Ohara O, Tanaka A, Kotani H, Miyajima N and Nomura N. (1996) Prediction of the coding sequences of unidentified human genes. VI. The coding sequences of 80 new genes (KIAA0201-KIAA0280) deduced by analysis of cDNA clones from cell line KG1 and brain. DNA Res. 3: 321-9, 341-54 [PMID:9039502]

211. Nakayama J, Fu YH, Clark AM, Nakahara S, Hamano K, Iwasaki N, Matsui A, Arinami T and Ptácek LJ. (2002) A nonsense mutation of the MASS1 gene in a family with febrile and afebrile seizures. Ann. Neurol. 52: 654-7 [PMID:12402266]

212. Nakayama J, Hamano K, Iwasaki N, Nakahara S, Horigome Y, Saitoh H, Aoki T, Maki T, Kikuchi M and Migita T et al.. (2000) Significant evidence for linkage of febrile seizures to chromosome 5q14-q15.Hum. Mol. Genet. 9: 87-91 [PMID:10587582]

213. Nakayama M, Nakajima D, Nagase T, Nomura N, Seki N and Ohara O. (1998) Identification of highmolecular-weight proteins with multiple EGF-like motifs by motif-trap screening. Genomics 51: 27-34 [PMID:9693030]

214. Nechiporuk T, Urness LD and Keating MT. (2001) ETL, a novel seven-transmembrane receptor that is developmentally regulated in the heart. ETL is a member of the secretin family and belongs to the epidermal growth factor-seven-transmembrane subfamily. J. Biol. Chem. 276: 4150-7 [PMID:11050079] 
215. Nie T, Hui X, Gao X, Li K, Lin W, Xiang X, Ding M, Kuang Y, Xu A and Fei kt al.. (2012) Adipose tissue deletion of Gpr116 impairs insulin sensitivity through modulation of adipose function. FEBS Lett. 586: 3618-25 [PMID:22971422]

216. Nikkila H, McMillan DR, Nunez BS, Pascoe L, Curnow KM and White PC. (2000) Sequence similarities between a novel putative $\mathrm{G}$ protein-coupled receptor and $\mathrm{Na}+/ \mathrm{Ca} 2+$ exchangers define a cation binding domain. Mol. Endocrinol. 14: 1351-64 [PMID:10976914]

217. Nishimori H, Shiratsuchi T, Urano T, Kimura Y, Kiyono K, Tatsumi K, Yoshida S, Ono M, Kuwano M, Nakamura $Y$ and Tokino T. (1997) A novel brain-specific p53-target gene, BAl1, containing thrombospondin type 1 repeats inhibits experimental angiogenesis. Oncogene 15: 2145-2150 [PMID:9393972]

218. Nishimura T, Honda $\mathrm{H}$ and Takeichi M. (2012) Planar cell polarity links axes of spatial dynamics in neuraltube closure. Cell 149: 1084-97 [PMID:22632972]

219. Nordström KJ, Fredriksson R and Schiöth HB. (2008) The amphioxus (Branchiostoma floridae) genome contains a highly diversified set of G protein-coupled receptors. BMC Evol. Biol. 8: 9 [PMID:18199322]

220. O'Connell RM, Rao DS, Chaudhuri AA and Baltimore D. (2010) Physiological and pathological roles for microRNAs in the immune system. Nat. Rev. Immunol. 10: 111-22 [PMID:20098459]

221. O'Sullivan ML, de Wit J, Savas JN, Comoletti D, Otto-Hitt S, Yates 3rd JR and Ghosh A. (2012) FLRT proteins are endogenous latrophilin ligands and regulate excitatory synapse development. Neuron 73: 90310 [PMID:22405201]

222. Obermann H, Samalecos A, Osterhoff C, Schröder B, Heller R and Kirchhoff C. (2003) HE6, a two-subunit heptahelical receptor associated with apical membranes of efferent and epididymal duct epithelia. Mol. Reprod. Dev. 64: 13-26 [PMID:12420295]

223. Oda $\mathrm{K}$, Shiratsuchi T, Nishimori H, Inazawa J, Yoshikawa $H$, Taketani $Y$, Nakamura $Y$ and Tokino $T$. (1999) Identification of BAIAP2 (BAl-associated protein 2), a novel human homologue of hamster IRSp53, whose SH3 domain interacts with the cytoplasmic domain of BAl1. Cytogenet. Cell Genet. 84: 75-82 [PMID:10343108]

224. Okajima D, Kudo $G$ and Yokota H. (2011) Antidepressant-like behavior in brain-specific angiogenesis inhibitor 2-deficient mice. J Physiol Sci 61: 47-54 [PMID:21110148]

225. Okajima D, Kudo G and Yokota H. (2010) Brain-specific angiogenesis inhibitor 2 (BAl2) may be activated by proteolytic processing. J. Recept. Signal Transduct. Res. 30: 143-53 [PMID:20367554]

226. Okazaki N, F-Kikuno R, Ohara R, Inamoto S, Koseki H, Hiraoka S, Saga Y, Seino S, Nishimura M and Kaisho T et al.. (2004) Prediction of the coding sequences of mouse homologues of KIAA gene: IV. The complete nucleotide sequences of 500 mouse KIAA-homologous cDNAs identified by screening of terminal sequences of cDNA clones randomly sampled from size-fractionated libraries. DNA Res. 11: 205-18 [PMID:15368895]

227. Osterhoff C, Ivell R and Kirchhoff C. (1997) Cloning of a human epididymis-specific mRNA, HE6, encoding a novel member of the seven transmembrane-domain receptor superfamily. DNA Cell Biol. 16: 379-89 [PMID:9150425]

228. Ozkan A, Biçer A, Avşar T, Seker A, Toktaş ZO, Bozkurt SU, Başak AN and Kılıç T. (2012) Temporal expression analysis of angiogenesis-related genes in brain development. Vasc Cell 4: 16 [PMID:23020941]

229. Paavola KJ and Hall RA. (2012) Adhesion G protein-coupled receptors: signaling, pharmacology, and mechanisms of activation. Mol. Pharmacol. 82: 777-83 [PMID:22821233]

230. Paavola KJ, Sidik H, Zuchero JB, Eckart M and Talbot WS. (2014) Type IV collagen is an activating ligand for the adhesion G protein-coupled receptor GPR126. Sci Signa/7: ra76 [PMID:25118328]

231. Park D, Tosello-Trampont AC, Elliott MR, Lu M, Haney LB, Ma Z, Klibanov AL, Mandell JW and Ravichandran KS. (2007) BAl1 is an engulfment receptor for apoptotic cells upstream of the ELMO/Dock180/Rac module. Nature 450: 430-4 [PMID:17960134]

232. Parrini E, Ferrari AR, Dorn T, Walsh CA and Guerrini R. (2009) Bilateral frontoparietal polymicrogyria, Lennox-Gastaut syndrome, and GPR56 gene mutations. Epilepsia 50: 1344-53 [PMID:19016831]

233. Peng YM, van de Garde MD, Cheng KF, Baars PA, Remmerswaal EB, van Lier RA, Mackay CR, Lin HH 
and Hamann J. (2011) Specific expression of GPR56 by human cytotoxic lymphocytes. J. Leukoc. Biol. 90: 735-40 [PMID:21724806]

234. Petersen SC, Luo R, Liebscher I, Giera S, Jeong SJ, Mogha A, Ghidinelli M, Feltri ML, Schöneberg T and Piao $X$ et al.. (2015) The adhesion GPCR GPR126 has distinct, domain-dependent functions in Schwann cell development mediated by interaction with laminin-211. Neuron 85: 755-69 [PMID:25695270]

235. Piao X, Chang BS, Bodell A, Woods K, Benzeev B, Topcu M, Guerrini R, Goldberg-Stern H, Sztriha L and Dobyns WB et al.. (2005) Genotype-phenotype analysis of human frontoparietal polymicrogyria syndromes. Ann. Neurol. 58: 680-7 [PMID:16240336]

236. Piao X, Hill RS, Bodell A, Chang BS, Basel-Vanagaite L, Straussberg R, Dobyns WB, Qasrawi B, Winter RM and Innes AM et al.. (2004) G protein-coupled receptor-dependent development of human frontal cortex. Science 303: 2033-6 [PMID:15044805]

237. Pickering C, Hägglund M, Szmydynger-Chodobska J, Marques F, Palha JA, Waller L, Chodobski A, Fredriksson R, Lagerström MC and Schiöth HB. (2008) The Adhesion GPCR GPR125 is specifically expressed in the choroid plexus and is upregulated following brain injury. BMC Neurosci 9: 97 [PMID:18834514]

238. Plager DA, Kahl JC, Asmann YW, Nilson AE, Pallanch JF, Friedman O and Kita H. (2010) Gene transcription changes in asthmatic chronic rhinosinusitis with nasal polyps and comparison to those in atopic dermatitis. PLoS ONE 5: e11450 [PMID:20625511]

239. Prömel S, Waller-Evans H, Dixon J, Zahn D, Colledge WH, Doran J, Carlton MB, Grosse J, Schöneberg T and Russ AP et al.. (2012) Characterization and functional study of a cluster of four highly conserved orphan adhesion-GPCR in mouse. Dev. Dyn. 241: 1591-602 [PMID:22837050]

240. Qian YM, Haino M, Kelly K and Song WC. (1999) Structural characterization of mouse CD97 and study of its specific interaction with the murine decay-accelerating factor (DAF, CD55). Immunology 98: 303-11 [PMID:10540231]

241. Qu Y, Glasco DM, Zhou L, Sawant A, Ravni A, Fritzsch B, Damrau C, Murdoch JN, Evans S, Pfaff SL, Formstone C, Goffinet AM, Chandrasekhar A and Tissir F. (2010) Atypical cadherins Celsr1-3 differentially regulate migration of facial branchiomotor neurons in mice. J. Neurosci. 30: 9392-401 [PMID:20631168]

242. Quattrocchi CC, Zanni G, Napolitano A, Longo D, Cordelli DM, Barresi S, Randisi F, Valente EM, Verdolotti T and Genovese E et al.. (2013) Conventional magnetic resonance imaging and diffusion tensor imaging studies in children with novel GPR56 mutations: further delineation of a cobblestone-like phenotype. Neurogenetics 14: 77-83 [PMID:23274687]

243. Rahman MA, Ashton AC, Meunier FA, Davletov BA, Dolly JO and Ushkaryov YA. (1999) Norepinephrine exocytosis stimulated by alpha-latrotoxin requires both external and stored $\mathrm{Ca} 2+$ and is mediated by latrophilin, G proteins and phospholipase C. Philos. Trans. R. Soc. Lond., B, Biol. Sci.354: 379-86 [PMID:10212487]

244. Raible F, Tessmar-Raible K, Arboleda E, Kaller T, Bork P, Arendt D and Arnone MI. (2006) Opsins and clusters of sensory G-protein-coupled receptors in the sea urchin genome. Dev. Biol. 300: 461-75 [PMID:17067569]

245. Ravni A, Qu Y, Goffinet AM and Tissir F. (2009) Planar cell polarity cadherin Celsr1 regulates skin hair patterning in the mouse. J. Invest. Dermatol. 129: 2507-9 [PMID:19357712]

246. Regard JB, Sato IT and Coughlin SR. (2008) Anatomical profiling of G protein-coupled receptor expression. Cell 135: 561-71 [PMID:18984166]

247. Reiners J, van Wijk E, Märker T, Zimmermann U, Jürgens K, te Brinke H, Overlack N, Roepman R, Knipper M and Kremer $\mathrm{H}$ et al.. (2005) Scaffold protein harmonin (USH1C) provides molecular links between Usher syndrome type 1 and type 2. Hum. Mol. Genet. 14: 3933-43 [PMID:16301216]

248. Ribasés M, Ramos-Quiroga JA, Sánchez-Mora C, Bosch R, Richarte V, Palomar G, Gastaminza X, Bielsa A, Arcos-Burgos M and Muenke $M$ et al.. (2011) Contribution of LPHN3 to the genetic susceptibility to ADHD in adulthood: a replication study. Genes Brain Behav. 10: 149-57 [PMID:21040458]

249. Richter GH, Fasan A, Hauer K, Grunewald TG, Berns C, Rössler S, Naumann I, Staege MS, Fulda S and Esposito I et al.. (2013) G-Protein coupled receptor 64 promotes invasiveness and metastasis in Ewing 
sarcomas through PGF and MMP1. J. Pathol. 230: 70-81 [PMID:23338946]

250. Robinson A, Escuin S, Doudney K, Vekemans M, Stevenson RE, Greene ND, Copp AJ and Stanier P. (2012) Mutations in the planar cell polarity genes CELSR1 and SCRIB are associated with the severe neural tube defect craniorachischisis. Hum. Mutat. 33: 440-7 [PMID:22095531]

251. Sahly I, Dufour E, Schietroma C, Michel V, Bahloul A, Perfettini I, Pepermans E, Estivalet A, Carette D and Aghaie A et al.. (2012) Localization of Usher 1 proteins to the photoreceptor calyceal processes, which are absent from mice. J. Cell Biol. 199: 381-99 [PMID:23045546]

252. Schaller E, Macfarlane AJ, Rupec RA, Gordon S, McKnight AJ and Pfeffer K. (2002) Inactivation of the F4/80 glycoprotein in the mouse germ line. Mol. Cell. Biol. 22: 8035-43 [PMID:12391169]

253. Schebesta A, McManus S, Salvagiotto G, Delogu A, Busslinger GA and Busslinger M. (2007) Transcription factor Pax5 activates the chromatin of key genes involved in B cell signaling, adhesion, migration, and immune function. Immunity 27: 49-63 [PMID:17658281]

254. Scholz N, Gehring J, Guan C, Ljaschenko D, Fischer R, Lakshmanan V, Kittel RJ and Langenhan T. (2015) The adhesion GPCR latrophilin/CIRL shapes mechanosensation. Cell Rep 11: 866-874 [PMID:25937282]

255. Seandel M, Falciatori I, Shmelkov SV, Kim J, James D and Rafii S. (2008) Niche players: spermatogonial progenitors marked by GPR125. Cell Cycle 7: 135-40 [PMID:18256534]

256. Seandel M, James D, Shmelkov SV, Falciatori I, Kim J, Chavala S, Scherr DS, Zhang F, Torres R and Gale NW et al.. (2007) Generation of functional multipotent adult stem cells from GPR125+ germline progenitors. Nature 449: 346-50 [PMID:17882221]

257. Senger DR, Perruzzi CA, Papadopoulos-Sergiou A and Van de Water L. (1994) Adhesive properties of osteopontin: regulation by a naturally occurring thrombin-cleavage in close proximity to the GRGDS cellbinding domain. Mol. Biol. Cell 5: 565-74 [PMID:7522656]

258. Shashidhar S, Lorente G, Nagavarapu U, Nelson A, Kuo J, Cummins J, Nikolich K, Urfer R and Foehr ED. (2005) GPR56 is a GPCR that is overexpressed in gliomas and functions in tumor cell adhesion.

Oncogene 24: 1673-82 [PMID:15674329]

259. Shima Y, Copeland NG, Gilbert DJ, Jenkins NA, Chisaka O, Takeichi M and Uemura T. (2002) Differential expression of the seven-pass transmembrane cadherin genes Celsr1-3 and distribution of the Celsr2 protein during mouse development. Dev. Dyn. 223: 321-32 [PMID:11891983]

260. Shima Y, Kawaguchi SY, Kosaka K, Nakayama M, Hoshino M, Nabeshima Y, Hirano T and Uemura T. (2007) Opposing roles in neurite growth control by two seven-pass transmembrane cadherins. Nat. Neurosci. 10: 963-9 [PMID:17618280]

261. Shima Y, Kengaku M, Hirano T, Takeichi M and Uemura T. (2004) Regulation of dendritic maintenance and growth by a mammalian 7-pass transmembrane cadherin. Dev. Cell 7: 205-16 [PMID:15296717]

262. Shiratsuchi T, Futamura M, Oda K, Nishimori H, Nakamura Y and Tokino T. (1998) Cloning and characterization of BAl-associated protein 1: a PDZ domain-containing protein that interacts with BAl1. Biochem. Biophys. Res. Commun. 247: 597-604 [PMID:9647739]

263. Shiratsuchi T, Nishimori H, Ichise H, Nakamura $Y$ and Tokino T. (1997) Cloning and characterization of BAI2 and BAI3, novel genes homologous to brain-specific angiogenesis inhibitor 1 (BAl1). Cytogenet. Cell Genet. 79: 103-8 [PMID:9533023]

264. Shiratsuchi T, Oda K, Nishimori H, Suzuki M, Takahashi E, Tokino T and Nakamura Y. (1998) Cloning and characterization of BAP3 (BAI-associated protein 3), a $\mathrm{C} 2$ domain-containing protein that interacts with BAl1. Biochem. Biophys. Res. Commun. 251: 158-65 [PMID:9790924]

265. Silva JP, Lelianova V, Hopkins C, Volynski KE and Ushkaryov Y. (2009) Functional cross-interaction of the fragments produced by the cleavage of distinct adhesion G-protein-coupled receptors. J. Biol. Chem. 284: 6495-506 [PMID:19124473]

266. Silva JP, Lelianova VG, Ermolyuk YS, Vysokov N, Hitchen PG, Berninghausen O, Rahman MA, Zangrandi A, Fidalgo $S$ and Tonevitsky AG et al.. (2011) Latrophilin 1 and its endogenous ligand Lasso/teneurin-2 form a high-affinity transsynaptic receptor pair with signaling capabilities. Proc. Natl. Acad. Sci. U.S.A. 108: 12113-8 [PMID:21724987] 
267. Singer K, Luo R, Jeong SJ and Piao X. (2013) GPR56 and the developing cerebral cortex: cells, matrix, and neuronal migration. Mol. Neurobiol. 47: 186-96 [PMID:23001883]

268. Skradski SL, Clark AM, Jiang H, White HS, Fu YH and Ptácek LJ. (2001) A novel gene causing a mendelian audiogenic mouse epilepsy. Neuron 31: 537-544 [PMID:11545713]

269. Sleckman BP, Khan WN, Xu W, Bassing CH, Malynn BA, Copeland NG, Bardon CG, Breit TM, Davidson L and Oltz EM et al.. (2000) Cloning and functional characterization of the early-lymphocyte-specific Pb99 gene. Mol. Cell. Biol. 20: 4405-10 [PMID:10825203]

270. St Croix B, Rago C, Velculescu V, Traverso G, Romans KE, Montgomery E, Lal A, Riggins GJ, Lengauer C and Vogelstein B et al.. (2000) Genes expressed in human tumor endothelium. Science 289: 1197-202 [PMID:10947988]

271. Stacey M, Chang GW, Davies JQ, Kwakkenbos MJ, Sanderson RD, Hamann J, Gordon S and Lin HH. (2003) The epidermal growth factor-like domains of the human EMR2 receptor mediate cell attachment through chondroitin sulfate glycosaminoglycans. Blood 102: 2916-24 [PMID:12829604]

272. Stacey M, Chang GW, Sanos SL, Chittenden LR, Stubbs L, Gordon S and Lin HH. (2002) EMR4, a novel epidermal growth factor (EGF)-TM7 molecule up-regulated in activated mouse macrophages, binds to a putative cellular ligand on B lymphoma cell line A20. J. Biol. Chem. 277: 29283-93 [PMID:12023293]

273. Stacey M, Lin HH, Hilyard KL, Gordon S and McKnight AJ. (2001) Human epidermal growth factor (EGF) module-containing mucin-like hormone receptor 3 is a new member of the EGF-TM7 family that recognizes a ligand on human macrophages and activated neutrophils. J. Biol. Chem. 276: 18863-70 [PMID:11279179]

274. Stehlik C, Kroismayr R, Dorfleutner A, Binder BR and Lipp J. (2004) VIGR--a novel inducible adhesion family G-protein coupled receptor in endothelial cells. FEBS Lett. 569: 149-55 [PMID:15225624]

275. Steinert M, Wobus M, Boltze C, Schütz A, Wahlbuhl M, Hamann J and Aust G. (2002) Expression and regulation of CD97 in colorectal carcinoma cell lines and tumor tissues. Am. J. Pathol. 161: 1657-67 [PMID:12414513]

276. Stevens CF and Williams JH. (2000) "Kiss and run" exocytosis at hippocampal synapses.Proc. Natl. Acad. Sci. U.S.A. 97: 12828-33 [PMID:11050187]

277. Sugimura R, He XC, Venkatraman A, Arai F, Box A, Semerad C, Haug JS, Peng L, Zhong XB and Suda T et al.. (2012) Noncanonical Wnt signaling maintains hematopoietic stem cells in the niche.Cell 150: 351-65 [PMID:22817897]

278. Sugita S, Ichtchenko K, Khvotchev M and Südhof TC. (1998) alpha-Latrotoxin receptor CIRL/latrophilin 1 (CL1) defines an unusual family of ubiquitous G-protein-linked receptors. G-protein coupling not required for triggering exocytosis. J. Biol. Chem. 273: 32715-24 [PMID:9830014]

279. Suzuki G, Kanda Y, Nibuya M, Hiramoto T, Tanaka T, Shimizu K, Watanabe Y and Nomura S. (2007) Stress and electroconvulsive seizure differentially alter GPR56 expression in the adult rat brain. Brain Res. 1183: 21-31 [PMID:17945200]

280. Tarpey PS, Smith R, Pleasance E, Whibley A, Edkins S, Hardy C, O'Meara S, Latimer C, Dicks E and Menzies A et al.. (2009) A systematic, large-scale resequencing screen of X-chromosome coding exons in mental retardation. Nat. Genet. 41: 535-43 [PMID:19377476]

281. Terskikh AV, Easterday MC, Li L, Hood L, Kornblum HI, Geschwind DH and Weissman IL. (2001) From hematopoiesis to neuropoiesis: evidence of overlapping genetic programs. Proc. Natl. Acad. Sci. U.S.A. 98: 7934-9 [PMID:11438738]

282. Tissir F, Bar I, Jossin Y, De Backer O and Goffinet AM. (2005) Protocadherin Celsr3 is crucial in axonal tract development. Nat. Neurosci. 8: 451-7 [PMID:15778712]

283. Tissir F, De-Backer O, Goffinet AM and Lambert de Rouvroit C. (2002) Developmental expression profiles of Celsr (Flamingo) genes in the mouse. Mech. Dev. 112: 157-60 [PMID:11850187]

284. Tissir $F$ and Goffinet AM. (2006) Expression of planar cell polarity genes during development of the mouse CNS. Eur. J. Neurosci. 23: 597-607 [PMID:16487141]

285. Tissir F, Qu Y, Montcouquiol M, Zhou L, Komatsu K, Shi D, Fujimori T, Labeau J, Tyteca D, Courtoy P, Poumay Y, Uemura T and Goffinet AM. (2010) Lack of cadherins Celsr2 and Celsr3 impairs ependymal 
ciliogenesis, leading to fatal hydrocephalus. Nat. Neurosci. 13: $700-7$ [PMID:20473291]

286. Tobaben S, Südhof TC and Stahl B. (2002) Genetic analysis of alpha-latrotoxin receptors reveals functional interdependence of CIRL/latrophilin 1 and neurexin 1 alpha. J. Biol. Chem. 277: 6359-65 [PMID:11741895]

287. Towner RA, Jensen RL, Colman H, Vaillant B, Smith N, Casteel R, Saunders D, Gillespie DL, SilasiMansat R and Lupu F et al.. (2013) ELTD1, a potential new biomarker for gliomas.Neurosurgery 72: 7790; discussion 91 [PMID:23096411]

288. Tönjes A, Koriath M, Schleinitz D, Dietrich K, Böttcher Y, Rayner NW, Almgren P, Enigk B, Richter O, Rohm S, Fischer-Rosinsky A, Pfeiffer A, Hoffmann K, Krohn K, Aust G, Spranger J, Groop L, Blüher M, Kovacs P and Stumvoll M. (2009) Genetic variation in GPR133 is associated with height: genome wide association study in the self-contained population of Sorbs. Hum. Mol. Genet. 18: 4662-8 [PMID:19729412]

289. Urano T, Shiraki M, Yagi H, Ito M, Sasaki N, Sato M, Ouchi Y and Inoue S. (2012) GPR98/Gpr98 gene is involved in the regulation of human and mouse bone mineral density. J. Clin. Endocrinol. Metab. 97: E56574 [PMID:22419726]

290. Usui T, Shima Y, Shimada Y, Hirano S, Burgess RW, Schwarz TL, Takeichi M and Uemura T. (1999) Flamingo, a seven-pass transmembrane cadherin, regulates planar cell polarity under the control of Frizzled. Cell 98: 585-95 [PMID:10490098]

291. Vakonakis I, Langenhan T, Prömel S, Russ A and Campbell ID. (2008) Solution structure and sugarbinding mechanism of mouse latrophilin-1 RBL: a 7TM receptor-attached lectin-like domain. Structure 16: 944-53 [PMID:18547526]

292. Vallon M, Aubele P, Janssen KP and Essler M. (2012) Thrombin-induced shedding of tumour endothelial marker 5 and exposure of its RGD motif are regulated by cell-surface protein disulfide-isomerase. Biochem. J. 441: 937-44 [PMID:22013897]

293. Vallon M and Essler M. (2006) Proteolytically processed soluble tumor endothelial marker (TEM) 5 mediates endothelial cell survival during angiogenesis by linking integrin alpha(v)beta3 to glycosaminoglycans. J. Biol. Chem. 281: 34179-88 [PMID:16982628]

294. Vallon M, Rohde F, Janssen KP and Essler M. (2010) Tumor endothelial marker 5 expression in endothelial cells during capillary morphogenesis is induced by the small GTPase Rac and mediates contact inhibition of cell proliferation. Exp. Cell Res. 316: 412-21 [PMID:19853600]

295. van Eijk M, Aust G, Brouwer MS, van Meurs M, Voerman JS, Dijke IE, Pouwels W, Sändig I, Wandel E, Aerts JM, Boot RG, Laman JD and Hamann J. (2010) Differential expression of the EGF-TM7 family members CD97 and EMR2 in lipid-laden macrophages in atherosclerosis, multiple sclerosis and Gaucher disease. Immunol. Lett. 129: 64-71 [PMID:20167235]

296. van Pel M, Hagoort $H$, Hamann J and Fibbe WE. (2008) CD97 is differentially expressed on murine hematopoietic stem-and progenitor-cells. Haematologica 93: 1137-44 [PMID:18603564]

297. van Wijk E, van der Zwaag B, Peters T, Zimmermann U, Te Brinke H, Kersten FF, Märker T, Aller E, Hoefsloot LH and Cremers CW et al.. (2006) The DFNB31 gene product whirlin connects to the Usher protein network in the cochlea and retina by direct association with USH2A and VLGR1. Hum. Mol. Genet. 15: 751-65 [PMID:16434480]

298. Vanti WB, Nguyen T, Cheng R, Lynch KR, George SR and O'Dowd BF. (2003) Novel human G-proteincoupled receptors. Biochem. Biophys. Res. Commun. 305: 67-71 [PMID:12732197]

299. Vassilatis DK, Hohmann JG, Zeng H, Li F, Ranchalis JE, Mortrud MT, Brown A, Rodriguez SS, Weller JR and Wright AC et al.. (2003) The G protein-coupled receptor repertoires of human and mouse.Proc. Natl. Acad. Sci. U.S.A. 100: 4903-8 [PMID:12679517]

300. Veninga $H$, Becker S, Hoek RM, Wobus M, Wandel E, van der Kaa J, van der Valk M, de Vos AF, Haase $\mathrm{H}$ and Owens B et al.. (2008) Analysis of CD97 expression and manipulation: antibody treatment but not gene targeting curtails granulocyte migration. J. Immunol. 181: 6574-83 [PMID:18941248]

301. Veninga H, Hoek RM, de Vos AF, de Bruin AM, An FQ, van der Poll T, van Lier RA, Medof ME and Hamann J. (2011) A novel role for CD55 in granulocyte homeostasis and anti-bacterial host defense. PLoS ONE 6: e24431 [PMID:21984892] 
302. Visser L, de Vos AF, Hamann J, Melief MJ, van Meurs M, van Lier RA, Laman JD and Hintzen RQ. (2002) Expression of the EGF-TM7 receptor CD97 and its ligand CD55 (DAF) in multiple sclerosis. J.

Neuroimmunol. 132: 156-63 [PMID:12417446]

303. Volynski KE, Capogna M, Ashton AC, Thomson D, Orlova EV, Manser CF, Ribchester RR and Ushkaryov YA. (2003) Mutant alpha-latrotoxin (LTXN4C) does not form pores and causes secretion by receptor stimulation: this action does not require neurexins. J. Biol. Chem. 278: 31058-66 [PMID:12782639]

304. Volynski KE, Silva JP, Lelianova VG, Atiqur Rahman M, Hopkins C and Ushkaryov YA. (2004) Latrophilin fragments behave as independent proteins that associate and signal on binding of LTX(N4C). EMBO J. 23: 4423-33 [PMID:15483624]

305. Waller-Evans H, Prömel S, Langenhan T, Dixon J, Zahn D, Colledge WH, Doran J, Carlton MB, Davies B and Aparicio SA et al.. (2010) The orphan adhesion-GPCR GPR126 is required for embryonic development in the mouse. PLOS ONE 5: e14047 [PMID:21124978]

306. Wallgard E, Larsson E, He L, Hellström M, Armulik A, Nisancioglu MH, Genove G, Lindahl P and Betsholtz C. (2008) Identification of a core set of 58 gene transcripts with broad and specific expression in the microvasculature. Arterioscler. Thromb. Vasc. Biol. 28: 1469-76 [PMID:18483404]

307. Wallis D, Hill DS, Mendez IA, Abbott LC, Finnell RH, Wellman PJ and Setlow B. (2012) Initial characterization of mice null for Lphn3, a gene implicated in ADHD and addiction. Brain Res. 1463: 85-92 [PMID:22575564]

308. Wandel E, Saalbach A, Sittig D, Gebhardt C and Aust G. (2012) Thy-1 (CD90) is an interacting partner for CD97 on activated endothelial cells. J. Immunol. 188: 1442-50 [PMID:22210915]

309. Wang T, Tian L, Haino M, Gao JL, Lake R, Ward Y, Wang H, Siebenlist U, Murphy PM and Kelly K. (2007) Improved antibacterial host defense and altered peripheral granulocyte homeostasis in mice lacking the adhesion class G protein receptor CD97. Infect. Immun. 75: 1144-53 [PMID:17158902]

310. Wang T, Ward Y, Tian L, Lake R, Guedez L, Stetler-Stevenson WG and Kelly K. (2005) CD97, an adhesion receptor on inflammatory cells, stimulates angiogenesis through binding integrin counterreceptors on endothelial cells. Blood 105: 2836-44 [PMID:15576472]

311. Ward Y, Lake R, Martin PL, Killian K, Salerno P, Wang T, Meltzer P, Merino M, Cheng SY and Santoro M et al.. (2013) CD97 amplifies LPA receptor signaling and promotes thyroid cancer progression in a mouse model. Oncogene 32: 2726-38 [PMID:22797060]

312. Ward Y, Lake R, Yin JJ, Heger CD, Raffeld M, Goldsmith PK, Merino M and Kelly K. (2011) LPA receptor heterodimerizes with CD97 to amplify LPA-initiated RHO-dependent signaling and invasion in prostate cancer cells. Cancer Res. 71: 7301-11 [PMID:21978933]

313. Weston MD, Luijendijk MW, Humphrey KD, Möller C and Kimberling WJ. (2004) Mutations in the VLGR1 gene implicate G-protein signaling in the pathogenesis of Usher syndrome type II. Am. J. Hum. Genet. 74: 357-66 [PMID:14740321]

314. White GR, Varley JM and Heighway J. (1998) Isolation and characterization of a human homologue of the latrophilin gene from a region of 1p31.1 implicated in breast cancer. Oncogene 17: 3513-9 [PMID:10030676]

315. Wilde C, Fischer L, Lede V, Kirchberger J, Rothemund S, Schöneberg T and Liebscher I. (2016) The constitutive activity of the adhesion GPCR GPR114/ADGRG5 is mediated by its tethered agonist. FASEB J. 30: 666-73 [PMID:26499266]

316. Wobus M, Vogel B, Schmücking E, Hamann J and Aust G. (2004) N-glycosylation of CD97 within the EGF domains is crucial for epitope accessibility in normal and malignant cells as well as CD55 ligand binding. Int. J. Cancer 112: 815-22 [PMID:15386373]

317. Wu J, Lei L, Wang S, Gu D and Zhang J. (2012) Immunohistochemical expression and prognostic value of CD97 and its ligand CD55 in primary gallbladder carcinoma. J. Biomed. Biotechnol. 2012: 587672 [PMID:22547928]

318. Wu Q and Maniatis T. (2000) Large exons encoding multiple ectodomains are a characteristic feature of protocadherin genes. Proc. Natl. Acad. Sci. U.S.A. 97: 3124-9 [PMID:10716726]

319. Xiao J, Jiang H, Zhang R, Fan G, Zhang Y, Jiang D and Li H. (2012) Augmented cardiac hypertrophy in 
response to pressure overload in mice lacking ELTD1. PLoS ONE 7: e35779 [PMID:22606234]

320. Xu L, Begum S, Hearn JD and Hynes RO. (2006) GPR56, an atypical G protein-coupled receptor, binds tissue transglutaminase, TG2, and inhibits melanoma tumor growth and metastasis. Proc. Natl. Acad. Sci. U.S.A. 103: 9023-8 [PMID:16757564]

321. Xu L and Hynes RO. (2007) GPR56 and TG2: possible roles in suppression of tumor growth by the microenvironment. Cell Cycle 6: 160-5 [PMID:17314516]

322. Yagi H, Takamura Y, Yoneda T, Konno D, Akagi Y, Yoshida K and Sato M. (2005) Vlgr1 knockout mice show audiogenic seizure susceptibility. J. Neurochem. 92: 191-202 [PMID:15606908]

323. Yagi H, Tokano H, Maeda M, Takabayashi T, Nagano T, Kiyama H, Fujieda S, Kitamura K and Sato M. (2007) Vlgr1 is required for proper stereocilia maturation of cochlear hair cells. Genes Cells 12: 235-50 [PMID:17295842]

324. Yamada Y, Fuku N, Tanaka M, Aoyagi Y, Sawabe M, Metoki N, Yoshida H, Satoh K, Kato K, Watanabe S, Nozawa Y, Hasegawa A and Kojima T. (2009) Identification of CELSR1 as a susceptibility gene for ischemic stroke in Japanese individuals by a genome-wide association study. Atherosclerosis 207: 144-9 [PMID:19403135]

325. Yamamoto Y, Irie K, Asada M, Mino A, Mandai K and Takai Y. (2004) Direct binding of the human homologue of the Drosophila disc large tumor suppressor gene to seven-pass transmembrane proteins, tumor endothelial marker 5 (TEM5), and a novel TEM5-like protein. Oncogene 23: 3889-97 [PMID:15021905]

326. Yang J, Liu X, Zhao Y, Adamian M, Pawlyk B, Sun X, McMillan DR, Liberman MC and Li T. (2010) Ablation of whirlin long isoform disrupts the USH2 protein complex and causes vision and hearing loss. PLoS Genet. 6: e1000955 [PMID:20502675]

327. Yang L, Chen G, Mohanty S, Scott G, Fazal F, Rahman A, Begum S, Hynes RO and Xu L. (2011) GPR56 Regulates VEGF production and angiogenesis during melanoma progression. Cancer Res. 71: 5558-68 [PMID:21724588]

328. Yates LL, Papakrivopoulou J, Long DA, Goggolidou P, Connolly JO, Woolf AS and Dean CH. (2010) The planar cell polarity gene Vangl2 is required for mammalian kidney-branching morphogenesis and glomerular maturation. Hum. Mol. Genet. 19: 4663-76 [PMID:20843830]

329. Yates LL, Schnatwinkel C, Murdoch JN, Bogani D, Formstone CJ, Townsend S, Greenfield A, Niswander LA and Dean CH. (2010) The PCP genes Celsr1 and Vangl2 are required for normal lung branching morphogenesis. Hum. Mol. Genet. 19: 2251-67 [PMID:20223754]

330. Ying G, Wu S, Hou R, Huang W, Capecchi MR and Wu Q. (2009) The protocadherin gene Celsr3 is required for interneuron migration in the mouse forebrain. Mol. Cell. Biol. 29: 3045-61 [PMID:19332558]

331. Yona S, Lin HH, Dri P, Davies JQ, Hayhoe RP, Lewis SM, Heinsbroek SE, Brown KA, Perretti M and Hamann J et al.. (2008) Ligation of the adhesion-GPCR EMR2 regulates human neutrophil function. FASEB J. 22: 741-51 [PMID:17928360]

332. Yona S, Lin HH, Siu WO, Gordon S and Stacey M. (2008) Adhesion-GPCRs: emerging roles for novel receptors. Trends Biochem. Sci. 33: 491-500 [PMID:18789697]

333. Zallocchi M, Delimont D, Meehan DT and Cosgrove D. (2012) Regulated vesicular trafficking of specific PCDH15 and VLGR1 variants in auditory hair cells. J. Neurosci. 32: 13841-59 [PMID:23035094]

334. Zallocchi M, Meehan DT, Delimont D, Rutledge J, Gratton MA, Flannery J and Cosgrove D. (2012) Role for a novel Usher protein complex in hair cell synaptic maturation. PLoS ONE 7: e30573 [PMID:22363448]

335. Zencir S, Ovee M, Dobson MJ, Banerjee M, Topcu Z and Mohanty S. (2011) Identification of brain-specific angiogenesis inhibitor 2 as an interaction partner of glutaminase interacting protein. Biochem. Biophys. Res. Commun. 411: $792-7$ [PMID:21787750]

336. Zendman AJ, Cornelissen IM, Weidle UH, Ruiter DJ and van Muijen GN. (1999) TM7XN1, a novel human EGF-TM7-like cDNA, detected with mRNA differential display using human melanoma cell lines with different metastatic potential. FEBS Lett. 446: 292-8 [PMID:10100861]

337. Zhang GJ, Chen TB, Connolly B, Lin SA, Hargreaves R, Vanko A, Bednar B, Macneil DJ, Sur C and Williams DL. (2009) In vivo optical imaging of LacZ expression using lacZ transgenic mice. Assay Drug 
Dev Technol 7: 391-9 [PMID:19689207]

338. Zhang H, Dong Y, Zhao H, Brooks JD, Hawthorn L, Nowak N, Marshall JR, Gao AC and Ip C. (2005) Microarray Data Mining for Potential Selenium Targets in Chemoprevention of Prostate Cancer. Cancer Genomics Proteomics 2: 97-114 [PMID:18548127]

339. Zhou L, Bar I, Achouri Y, Campbell K, De Backer O, Hebert JM, Jones K, Kessaris N, de Rouvroit CL, O'Leary D, Richardson WD, Goffinet AM and Tissir F. (2008) Early forebrain wiring: genetic dissection using conditional Celsr3 mutant mice. Science 320: 946-9 [PMID:18487195]

340. Zhou L, Qu Y, Tissir F and Goffinet AM. (2009) Role of the atypical cadherin Celsr3 during development of the internal capsule. Cereb. Cortex 19 Suppl 1: i114-9 [PMID:19349379]

341. Zhu D, Hunter SB, Vertino PM and Van Meir EG. (2011) Overexpression of MBD2 in glioblastoma maintains epigenetic silencing and inhibits the antiangiogenic function of the tumor suppressor gene BAl1. Cancer Res. 71: 5859-70 [PMID:21724586]

342. Ziegler J, Pody R, Coutinho de Souza P, Evans B, Saunders D, Smith N, Mallory S, Njoku C, Dong Y and Chen $\mathrm{H}$ et al.. (2017) ELTD1, an effective anti-angiogenic target for gliomas: preclinical assessment in mouse GL261 and human G55 xenograft glioma models. Neuro-oncology 19: 175-185 [PMID:27416955]

343. Zou J, Luo L, Shen Z, Chiodo VA, Ambati BK, Hauswirth WW and Yang J. (2011) Whirlin replacement restores the formation of the USH2 protein complex in whirlin knockout photoreceptors. Invest.

Ophthalmol. Vis. Sci. 52: 2343-51 [PMID:21212183] 